\title{
SIMULATED EFFECTS OF ALTERNATIVE WITHDRAWAL STRATEGIES ON GROUND-WATER- FLOW PATTERNS, NEW JERSEY PINELANDS
}

By Edward Modica

U. S. GEOLOGICAL SURVEY

Water-Resources Investigations Report 95-4133

Prepared in cooperation with the NEW JERSEY DEPARTMENT OF ENVIRONMENTAL PROTECTION

West Trenton, New Jersey 


\title{
DEPARTMENT OF THE INTERIOR \\ BRUCE BABBITT, Secretary
}

\author{
U. S. GEOLOGICAL SURVEY
}

Gordon P. Eaton, Director

For additional information

write to:

District Chief

U. S. Geological Survey

Mountain View Office Park

810 Bear Tavern Road

Suite 206

West Trenton, NJ 08628
Copies of this report can be purchased from:

U. S. Geological Survey Earth Science Information Center Open-File Reports Section Box 25286, MS 517 Denver Federal Center Denver, CO 80225-0046 


\section{CONTENTS}

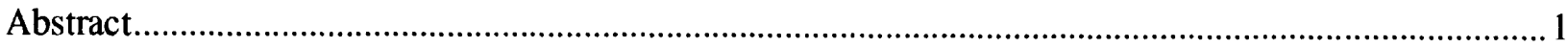

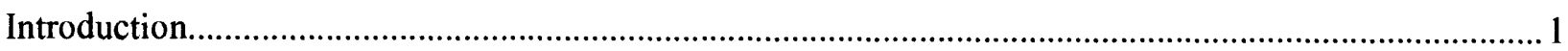

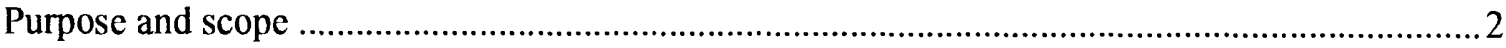

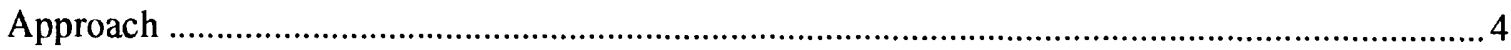

Drainage basins in the central part of the New Jersey Pinelands ................................................ 4

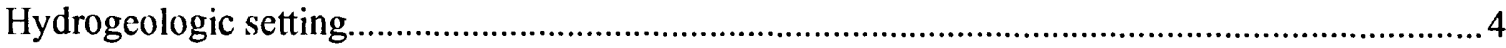

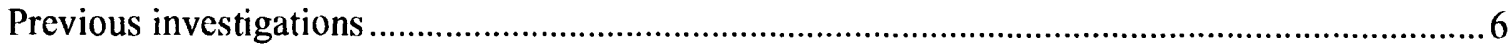

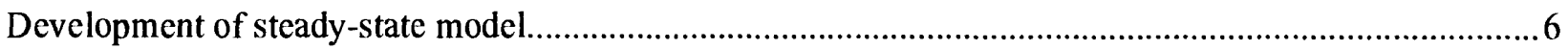

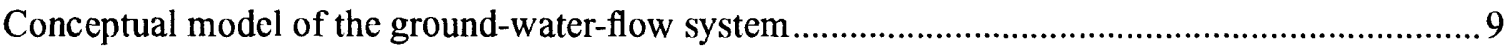

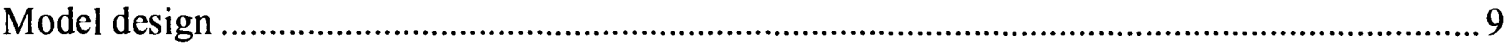

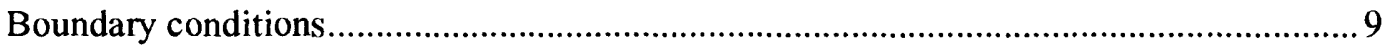

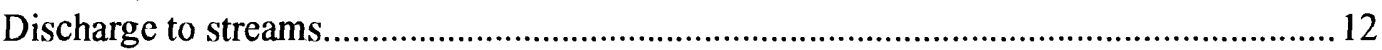

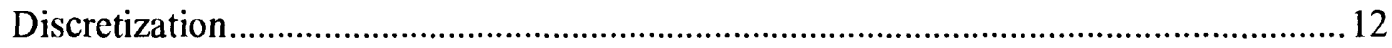

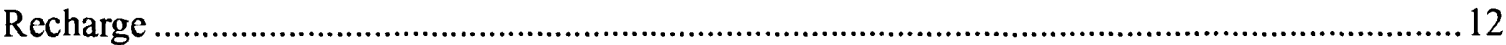

Hydraulic properties of the Kirkwood-Cohansey aquifer system and underlying units .............. 14

Performance and calibration criteria.............................................................................. 14

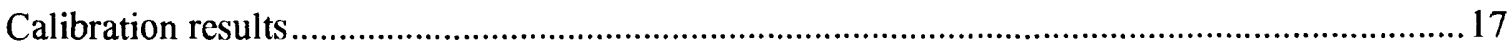

Characteristics of unstressed, steady-state flow in the upper Rancocas Creek and Wading

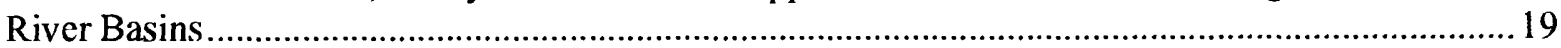

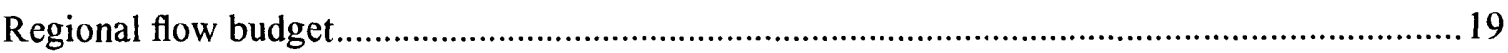

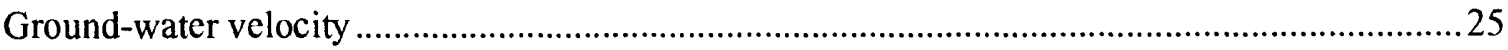

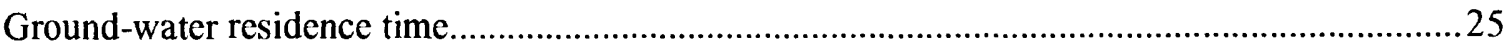

Source areas of flow in the McDonalds Branch-Middle Branch Basins area ...............................28

Simulated effects of alternative withdrawal strategies on ground-water-flow patterns.............................34

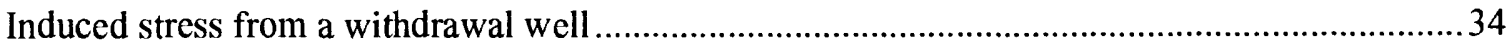

Induced stress caused by withdrawals from the Piney Point aquifer ....................................... 40

Effects of withdrawals on ground-water residence time .................................................... 40

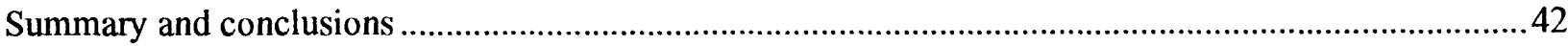

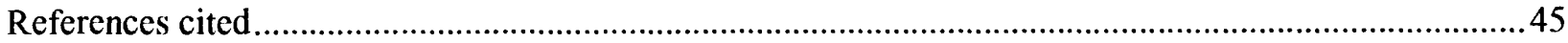

\section{ILLUSTRATIONS}

Figure 1. Map showing major drainage divides in the New Jersey Coastal Plain and adjacent drainage basins in the central part of the New Jersey Pinelands ................................ 3

2. Generalized hydrogeologic section through the upper part of the Rancocas Creek Basin, New Jersey Pinelands

3. Map showing areal distribution of the Piney Point and Vincentown aquifers within the modeled area, New Jersey Pinelands 7

4. Map showing areal distribution of the Cohansey Sand and the Kirkwood Formation in the modeled area, New Jersey Pinelands

5. Schematic diagram showing generalized pattern of ground-water flow beneath the upper part of the Rancocas Creek Basin, New Jersey Pinelands

6. Map showing horizontal discretization of aquifer and drainage network in the modeled area, New Jersey Pinelands. 


\section{ILLUSTRATIONS--Continued}

Figure 7. Schematic diagram showing vertical discretization of the ground-water-flow model and relation between aquifer units and model layers, New Jersey Pinelands

8. Hydrograph showing water levels in continuous-record observation well 05-0689 located in Lebanon State Forest, New Jersey, water years 1956-94

9. Map showing locations of drainage basins and streamflow-gaging stations in the modeled area, New Jersey Pinelands

10. Map showing simulated and interpreted water-table contours in the modeled area, New Jersey Pinelands

11. Map showing locations of wells in the modeled area used to calibrate the ground-waterflow model, New Jersey Pinelands

12. Map showing simulated horizontal ground-water-velocity vectors in the upper layer of the ground-water-flow model of the upper parts of the Rancocas Creek and Wading River Basins, New Jersey Pinelands.

13. Map showing simulated residence time of ground water in recharge areas at the water table in the ground-water-flow model of the upper parts of the Rancocas Creek and Wading River Basins, New Jersey Pinelands.

14. Simulated flow paths and travel times of particles in (A) map view and (B) cross-sectional view in column 42 of the ground-water-flow model of the upper parts of the Rancocas Creek and Wading River Basins, New Jersey Pinelands,

15. Map showing simulated source areas of ground-water flow to streams and seepage to the Piney Point aquifer in the subarea of the ground-water-flow model of the upper parts of the Rancocas Creek and Wading River Basins, New Jersey Pinelands, under unstressed conditions

16. Map showing streams in the subarea of the upper parts of the Rancocas Creek and Wading River Basins, New Jersey Pinelands, near the regional drainage divide

17. Maps showing (A) simulated source area of recharge to the Piney Point aquifer, and (B) simulated seepage area of flow to the Piney Point aquifer at the base of the Kirkwood-Cohansey aquifer system, in the subarea of the ground-water-flow model of the upper parts of the Rancocas Creck and Wading River Basins, New Jersey Pinelands, near the regional drainage divide

18. Map showing simulated source areas of ground-water flow to streams, to the Pincy Point aquifer, and to withdrawal well 1 located on the divide, in the subarea of the groundwater-flow model of the upper parts of the Rancocas Creck and Wading River Basins, New Jersey Pinelands, with ground-water withdrawals from withdrawal well 1 .

19. Map showing simulated source areas of ground-water flow to streams, to the Piney Point aquifer, and to withdrawal well 2 in the subarea of the ground-water-flow model of the upper parts of the Rancocas Creek and Wading River Basins, New Jersey Pinclands, with ground-water withdrawals from withdrawal well 2 .....

20. Map showing simulated source areas of ground-water flow to streams and to the Piney Point aquifer in the subarea of the ground-water-flow model of the upper parts of the Rancocas Creek and Wading River Basins, New Jersey Pinelands, with groundwater withdrawals from the Piney Point aquifer..... 


\section{ILLUSTRATIONS--Continued}

Page

Figure 21. Map showing simulated residence time under (A) unstressed conditions and (B) conditions of ground-water withdrawals from withdrawal well 1 in the subarea of the ground-water-flow model of the upper parts of the Rancocas Creek and Wading River Basins, New Jersey Pinelands

\section{TABLES}

Table 1. Values of hydraulic conductivity and recharge used in ground-water-flow model simulation of the upper parts of the Rancocas Creek and Wading River Basins, New Jersey Pinelands

2. Average measured water levels in wells and simulated head values for corresponding model cells, New Jersey Pinelands

3. Measured streamflow, calculated base flow, and simulated base flow at continuous- and partial-record gaging stations in the modeled area, New Jersey Pinelands

4. Measured streamflow, calculated base flow, and simulated base flow grouped into concurrent periods of record at continuous-record gaging stations in the modeled area, New Jersey Pinelands

5. Simulated ground-water budget for the ground-water-flow model of the upper parts of the Rancocas Creek and Wading River Basins, New Jersey Pinelands

6. Simulated ground-water budget for the subarea of the ground-water-flow model of the upper parts of the Rancocas Creek and Wading River Basins, New Jersey Pinelands, near the regional divide for four flow simulations 


\section{CONVERSION FACTORS AND VERTICAL DATUM}

$\begin{array}{lll}\text { Multiply } & \text { By } & \text { To obtain } \\ \text { foot }(\mathrm{ft}) & 0.3048 & \text { meter } \\ \text { mile }(\mathrm{mi}) & 1.609 & \text { kilometer } \\ \text { square mile }\left(\mathrm{mi}^{2}\right) & 2.59 & \text { square kilometer } \\ \text { inch per year }(\mathrm{in} / \mathrm{yr}) & 2.54 & \text { centimeter per year } \\ \text { foot per day }(\mathrm{ft} / \mathrm{d}) & 0.3048 & \text { meter per day } \\ \text { square foot per day }\left(\mathrm{ft}^{2} / \mathrm{d}\right) & 0.0929 & \text { square meter per day } \\ \text { cubic foot per second }\left(\mathrm{ft}^{3} / \mathrm{s}\right) & 0.0283 & \text { cubic meter per second } \\ \text { cubic foot per day }\left(\mathrm{ft}^{3} / \mathrm{d}\right) & 0.0283 & \text { cubic meter per day } \\ \text { million gallons per day }(\mathrm{Mgal} / \mathrm{d}) & 3.785 & \text { million liters per day }\end{array}$

Sea level: In this report "sea level" refers to the National Geodetic Vertical Datum of 1929 (NGVD of 1929) -- a geodetic datum derived from a general adjustment of the first-order level nets of both the United States and Canada, formerly called "Sea Level Datum of 1929." 


\title{
SIMULATED EFFECTS OF ALTERNATIVE WITHDRAWAL STRATEGIES ON GROUND-WATER-FLOW PATTERNS, NEW JERSEY PINELANDS
}

\author{
By Edward Modica
}

\begin{abstract}
A steady-state, three-dimensional ground-water-flow model of the unconfined part of the Kirkwood-Cohansey aquifer system beneath the upper parts of the Rancocas Creek and Wading River Basins in the New Jersey Pinelands was developed to (1) define ground-water-flow patterns and residence times in an aquifer system typical of the New Jersey Coastal Plain and (2) demonstrate the effects of alternative withdrawal strategies on ground-water-flow patterns and streams. Ground-water flow near the McDonalds-Middle Branch area was analyzed by using a particle tracker to demonstrate the effects of three hypothetical withdrawal scenarios on the configurations of source areas of ground-water flow to withdrawal wells, streams, and other discharge outlets in the Kirkwood-Cohansey aquifer system. Under natural conditions, more than 98 percent of the ground water in the part of the Kirkwood-Cohansey aquifer system underlying the upper Rancocas Creek and Wading River Basins enters the system as recharge. More than 87 percent of the ground water discharges to streams and wetlands. Ground-water seepage to the underlying Piney Point aquifer accounts for about 8 percent of discharge from the system. Areas near major drainage divides are the source of flow to distant parts of the system. Consequently, source areas of flow to small basins located near major drainage divides do not necessarily coincide with the physiographic boundaries of the basins. Ground-water residence times ranged from slightly greater than zero to about 200 years. Much of the ground water remained in the system for less than 20 years because it discharged to streams. Residence times of ground water were reduced significantly by persistent withdrawals. The sizes and shapes of source areas of flow to local stream systems and to the Piney Point aquifer are affected by the location of a withdrawal well. The source area of flow to the withdrawal well includes areas of the water table that would, under natural conditions, be incorporated into source areas of flow to streams or to the Piney Point aquifer. Simulated withdrawals of 1.85 million gallons per day ( $\mathrm{Mgal} / \mathrm{d})$ at the divide have negligible effects on source areas of ground-water flow to adjacent streams, but capture recharge that under natural conditions would flow deep into the aquifer. Simulated withdrawals of $1.85 \mathrm{Mgal} / \mathrm{d}$ located away from the divide, however, capture the most recharge from source areas of flow to adjacent streams. Large-scale regional withdrawals that cause a 10- to 15-foot decrease in heads in the Piney Point aquifer and divert $6.2 \mathrm{Mgal} / \mathrm{d}$ of ground water from the Kirkwood-Cohansey aquifer system increase the source area of flow to the Piney Point aquifer by diverting ground water from streams. Results of withdrawal simulations indicate that well-location strategies applied in the Kirkwood-Cohansey aquifer system can mitigate the adverse effects of withdrawals on streams and that large-scale regional withdrawals in confined aquifers can adversely effect streams although the effects are dispersed over numerous streams.
\end{abstract}

\section{INTRODUCTION}

The Coastal Plain of New Jersey contains a system of drainage basins and aquifers that are crucial to the State's water supply. Because the physical and chemical characteristics of the basins affect the quantity and quality of both surface runoff and recharge to the aquifer system, basins function as important controls on the region's water supply. The New Jersey Pinelands is a reserve area that encompasses the major drainage divides of the Coastal Plain and many of the area's hydrologically important drainage basins (fig. 1). The New Jersey Pinelands (or Pineland Reserve) is a 2,300- $\mathrm{mi}^{2}$ area that contains recre- 
ational, agricultural, and residential land. The Pinelands contains several forest preserves with abundant riparian and tidal wetlands that function as ecological buffering systems. Many of these wetlands are located along the boundary of the Pinelands where demand for ground water has increased as a result of continuing development.

In recent years, the potential effects of increased demands for ground water on basins located near rapidly developing areas have become a concern for water-supply managers. A major problem for State and municipal regulatory agencies is to allocate water needed to satisfy development while ensuring that such needs do not create excessive, long-term ground-water diversion from streams and adjacent wetland areas. In order to effectively regulate water supply near these areas, regulatory agencies need to link allocation criteria to hydrologic processes at both large and small scales on the basis of the characteristics of the basins and aquifers within their jurisdiction. Little information on the relation between regional-scale ground-water flow and localized flow in small drainage basins is available, however.

The major objectives of this study, conducted by the U. S. Geological Survey (USGS) in cooperation with the New Jersey Department of Environmental Protection, were to (1) define ground-water-flow patterns and residence times under natural conditions in selected drainage basins of the Pinelands located near major drainage divides and (2) demonstrate the effect of several alternative strategies for groundwater withdrawal from the Kirkwood-Cohansey aquifer system and Piney Point aquifer on the configuration of source areas of ground-water flow to streams and other discharge outlets in the area. In this report, "source area" refers to an area on the water table where recharge enters the ground-water system and flows to discharge outlets such as streams and withdrawal wells. The central part of the New Jersey Pinelands was selected for study because ground-water flow in this area is least affected by development; therefore, the unstressed ground-water-flow conditions in the unconfined aquifer in this area provide the best "index" of unstressed flow conditions with which to compare stressed flow conditions, especially near a major drainage divide, where ground-water flow is most sensitive to induced stresses. The results of this study demonstrate the cause-and-effect relations between withdrawal and ground-water diversion and illustrate some potentially unanticipated ground-water-flow responses to withdrawals near major divides and in multilayered aquifer systems under various hydrologic conditions.

\section{Purpose and Scope}

This report presents and interprets the results of one unstressed and three withdrawal simulations of ground-water flow in the part of the Kirkwood-Cohansey aquifer system beneath the Pinelands of the New Jersey Coastal Plain. A particle tracker was used to define ground-water-flow paths and to establish ground-water-residence times in the modeled system. A particle tracker was also used to define the configuration of the source areas of ground-water flow to streams, to the Piney Point aquifer, and to points of hypothetical withdrawal. The "source area" analysis was restricted to a subarea of the model of about 48 $\mathrm{mi}^{2}$ that includes McDonalds and Middle Branch Basins (fig. 16, farther on). Because the application of the model is qualitative rather than quantitative, model development and calibration were restricted to available hydrogeologic data collected during water years ${ }^{1} 1956-94$.

1. The 12-month period from October 1 through September 30, designated by the calendar year in which it ends. 


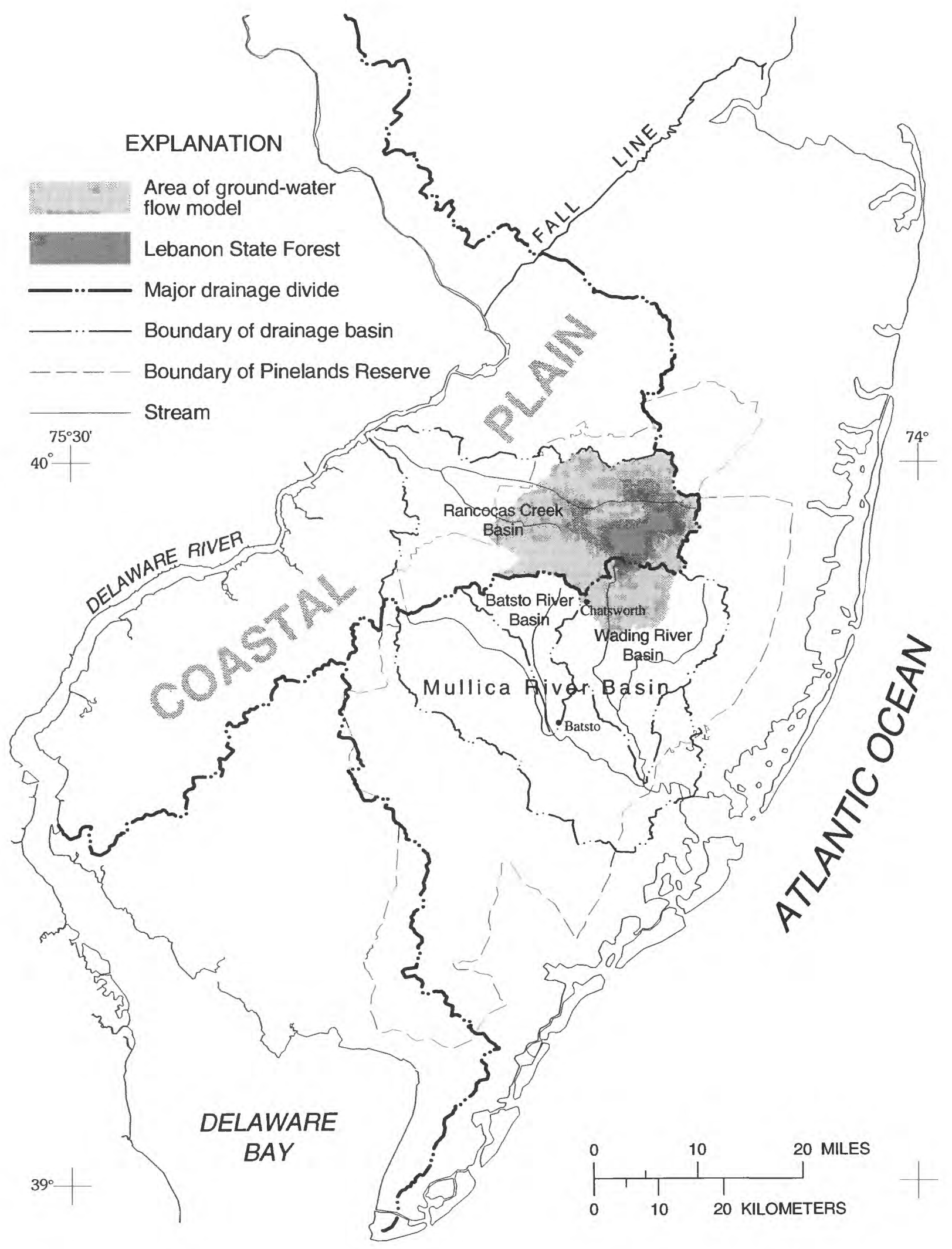

Figure 1. Major drainage divides in the New Jersey Coastal Plain and adjacent drainage basins in the central part of the New Jersey Pinelands. 


\section{Approach}

A steady-state, three-dimensional ground-water-flow model was developed for the upper parts of the Rancocas Creek and Wading River Basins. The finite-difference computer program Modflow (McDonald and Harbaugh, 1988) was used to simulate unconfined flow in the part of the KirkwoodCohansey aquifer system that underlies the basins. The particle-tracking postprocessor Modpath (Pollock, 1989) was used to determine the steady-state configuration of source areas of ground water that discharges to streams and to the underlying confined aquifer. The particle-tracking analysis was performed by using results of four different flow simulations -- one of natural (unstressed) hydrologic conditions and threc of different hypothetical ground-water-withdrawal conditions. This analysis was restricted to a subarea of the modeled domain that includes both McDonalds and Middle Branch Basins. Output from the particle tracker was used to determine ground-water residence times for the entire modeled area.

\section{Drainage Basins in the Central Part of the New Jersey Pinelands}

The Rancocas Creek and Wading River Basins are located in the central part of the New Jersey Pinelands on either side of a major drainage divide (fig. 1). Only the eastern part of Rancocas Creek Basin lies within the New Jersey Pinelands. The Rancocas Creek drains to the west, toward the Delaware River. The regional drainage divide defines the eastern and part of the southern boundary of the Rancocas Creek Basin. The upper parts of the Batsto and Wading River Basins adjoin the Rancocas Creek Basin on its southern boundary. The Batsto and Wading Rivers are part of the Mullica River Basin, which drain to Great Bay on the Atlantic Coast. The area chosen for a ground-water flow simulation, hereafter referred to as the "modeled area," includes the upper part of the Wading River Basin and the eastern (or upper) part of the Rancocas Creek Basin (fig. 1), which together cover about $220 \mathrm{mi}^{2}$. The modeled area includes Lebanon State Forest, which is located in the eastern part of the Rancocas Creek Basin. The Coastal Plain of New Jersey is characterized by gently rolling hills. The topographic relief within the modeled area is about $170 \mathrm{ft}$; maximum elevations are found at the major drainage divide at about $210 \mathrm{ft}$. Surface slopes typically vary from 2 to $10 \mathrm{ft} / \mathrm{mi}$. Because of the low relief, wetlands are common throughout the area. Artificial impoundments also are common in agricultural areas.

\section{Hydrogeologic Setting}

The geology near the upper parts of the Rancocas Creek and Wading River Basins consists of a layered sequence of unconsolidated marine deposits of Tertiary and Upper Cretaceous age that dip to the east-southeast. A generalized section through the hydrogeologic units that immediately underlie the modeled area is shown in figure 2. The Cohanscy Sand forms the upper part of the Kirkwood-Cohansey aquifer system; it is predominantly a quartz sand that contains minor amounts of pebbles, silty and clayey sand, and interbedded clay (Zapecza, 1989). The upper layers of the Kirkwood Formation form the lower part of the aquifer system and consist of fine- to medium-grained sand and silty sand. The aquifer system extends from the land surface to the clay at the base of the Kirkwood Formation. These clays, which make up the basal Kirkwood confining unit below the aquifer, are regionally extensive.

The uppermost layers of the Kirkwood Formation are hydraulically connected to the overlying Cohansey Sand. However, the hydraulic conductivity of the Kirkwood Formation is considered to be lower than that of the Cohansey Sand (Rhodehamel, 1973). The thickness of the sediments in the aquifer within the modeled area ranges from about $360 \mathrm{ft}$ beneath the drainage divide to 0 at their updip limit to the west, where the fine-grained basal sediments of the Kirkwood Formation crop out. Ground-water flow in the aquifer system generally is unconfined; however, the local deposits of interbedded clay create locally confined or perched conditions. 


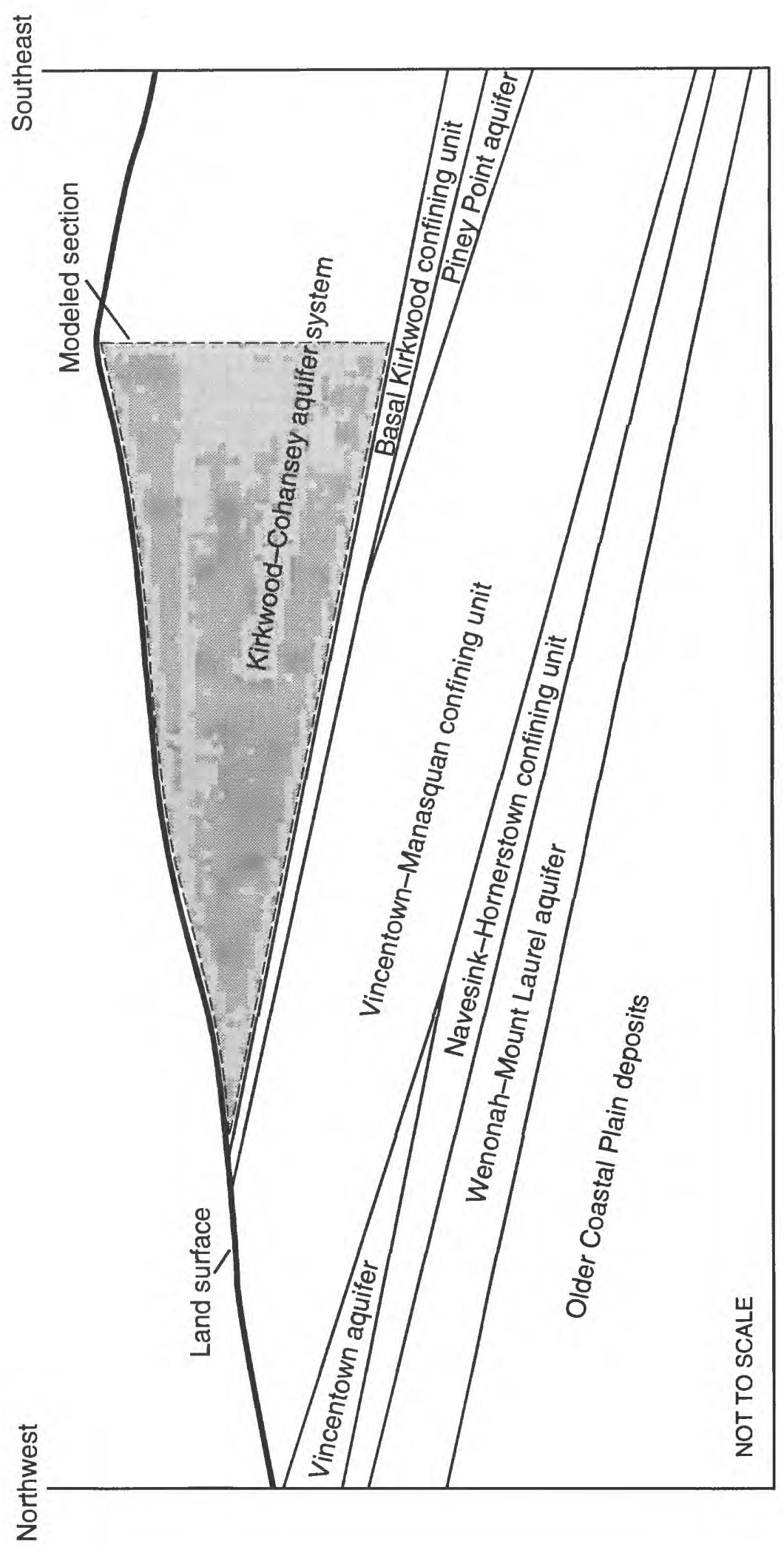

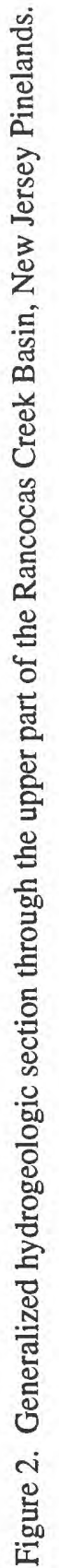


The Piney Point aquifer underlies part of the Kirkwood-Cohansey aquifer system in the castern part of the modeled area. The two aquifers are separated by about 50 to $100 \mathrm{ft}$ of basal Kirkwood clay. The Pincy Point aquifer consists of glauconitic quartz sand and shell beds, and unconformably overlies the Manasquan Formation. The Piney Point aquifer in the modeled area terminates about 5 mi east of the regional divide, where it pinches out along its updip extent about $200 \mathrm{ft}$ below the land surface.

The Vincentown aquifer underlies part of the Kirkwood-Cohansey aquifer system in the western part of the basin. The Kirkwood-Cohansey aquifer system and Vincentown aquifer are separated by the Vincentown-Manasquan confining unit, which is about $200 \mathrm{ft}$ thick in this area. The Vincentown aquifer is confined within the modeled area and pinches out downdip. The aquifer is composed of massive quartz sand and fossiliferous lime sand. The areal distribution of the Piney Point and Vincentown aquifers in the modeled area is shown in figure 3.

The outcrop pattern of the Kirkwood Formation and Cohansey Sand in the modeled area (Minard and Owens, 1963, 1964) is shown in figure 4. These units are overlain by a discontinuous veneer of fluvial outwash deposits, which are 10 to $20 \mathrm{ft}$ thick and consist of sand that is almost indistinguishable from the Cohansey Sand (Minard and Owens, 1975).

\section{Previous Investigations}

Studies that are related to the simulation of ground-water flow in the modeled area include Martin's (1990) simple, water-budget-oriented flow simulation of the unconfined Kirkwood-Cohansey aquifer system, which was conducted as part of the Regional Aquifer System Analysis of the Coastal Plain by the USGS. Harbaugh and Tilley (1984) developed a two-dimensional, areal, steady-state flow model for a $570-\mathrm{mi}^{2}$ area of the Mullica River Basin, parts of which overlap the modeled area for this study. Rhodehamel (1970) developed a hydrologic budget of the Pinelands and evaluated water-resource development in the region.

Studies involving various aspects of McDonalds Branch and adjacent streams located near headwaters of the Rancocas Creek Basin include Johnsson and Barringer (1993), who discuss the spatial and temporal variations in concentrations of chemical constituents in surface water and shallow ground water within the McDonalds Branch Basin; Lord and others (1990), who present hydrologic and water-chemistry data pertaining to acidic deposition in the McDonalds Branch Basin; and Zampella and Moore (1992), who establish relations between lowland vegetative communities and depth-to-water adjacent to tributaries within Lebanon State Forest.

\section{DEVELOPMENT OF STEADY-STATE MODEL}

A three-dimensional, steady-state model of unconfined ground-water flow was prepared for this study. Because much of the flow in the Kirkwood-Cohansey aquifer system is shallow flow within a relatively thin aquifer, a two-dimensional, areal-flow model can be used successfully to simulate flow in large parts of the region (Harbaugh and Tilley, 1984). However, for the aquifer system modeled in this study, it was assumed that the Piney Point aquifer and Kirkwood-Cohansey aquifer system are hydraulically connected and that their combined thickness near the regional drainage divide allows for deeper flow of ground water that ultimately discharges to distant areas in the system. Consequently, a three-dimensional flow model was used in order to simulate more accurately both vertical and horizontal components of flow in the system. 


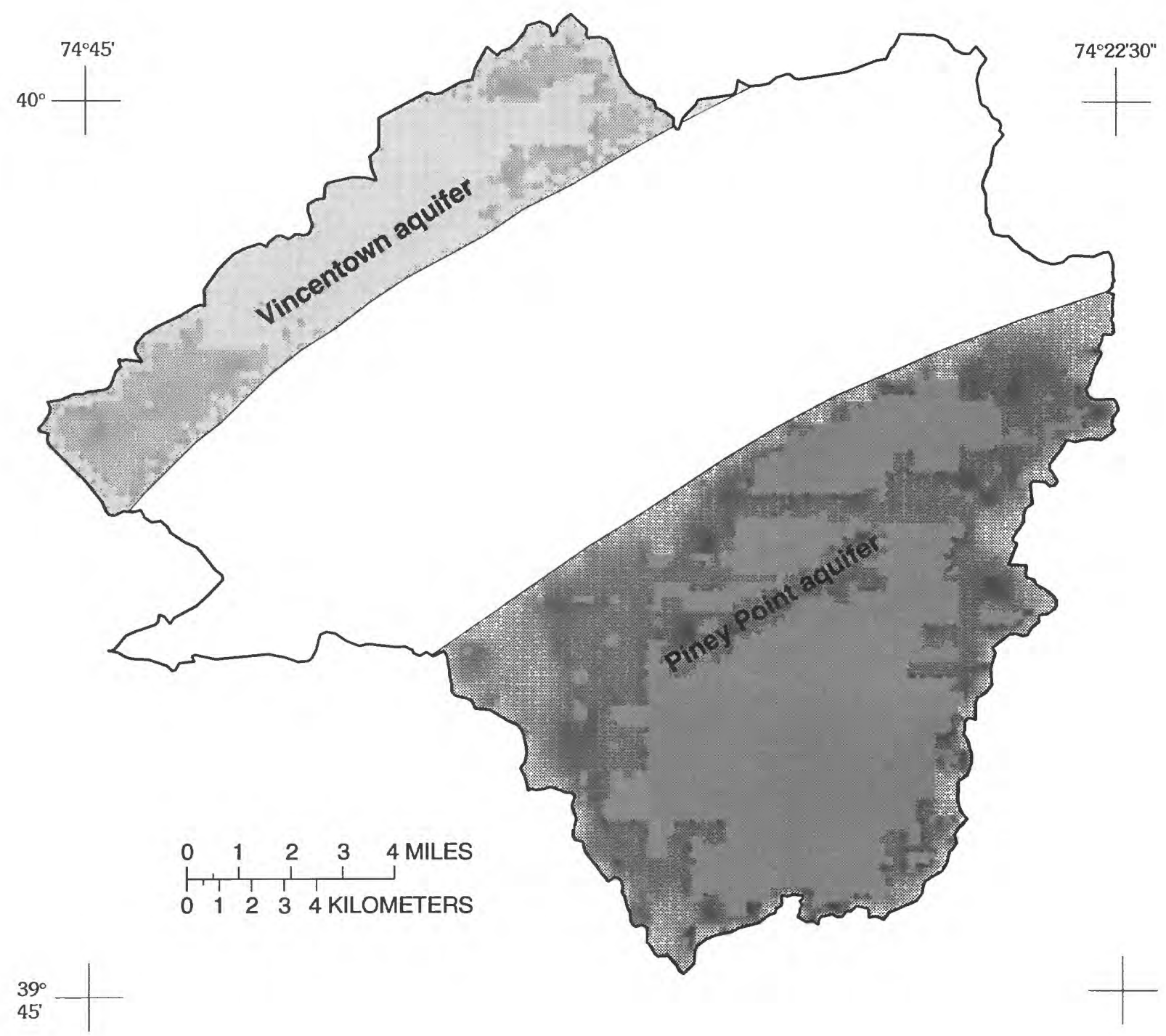

Figure 3. Areal distribution of the Piney Point and Vincentown aquifers within the modeled area, New Jersey Pinelands. 


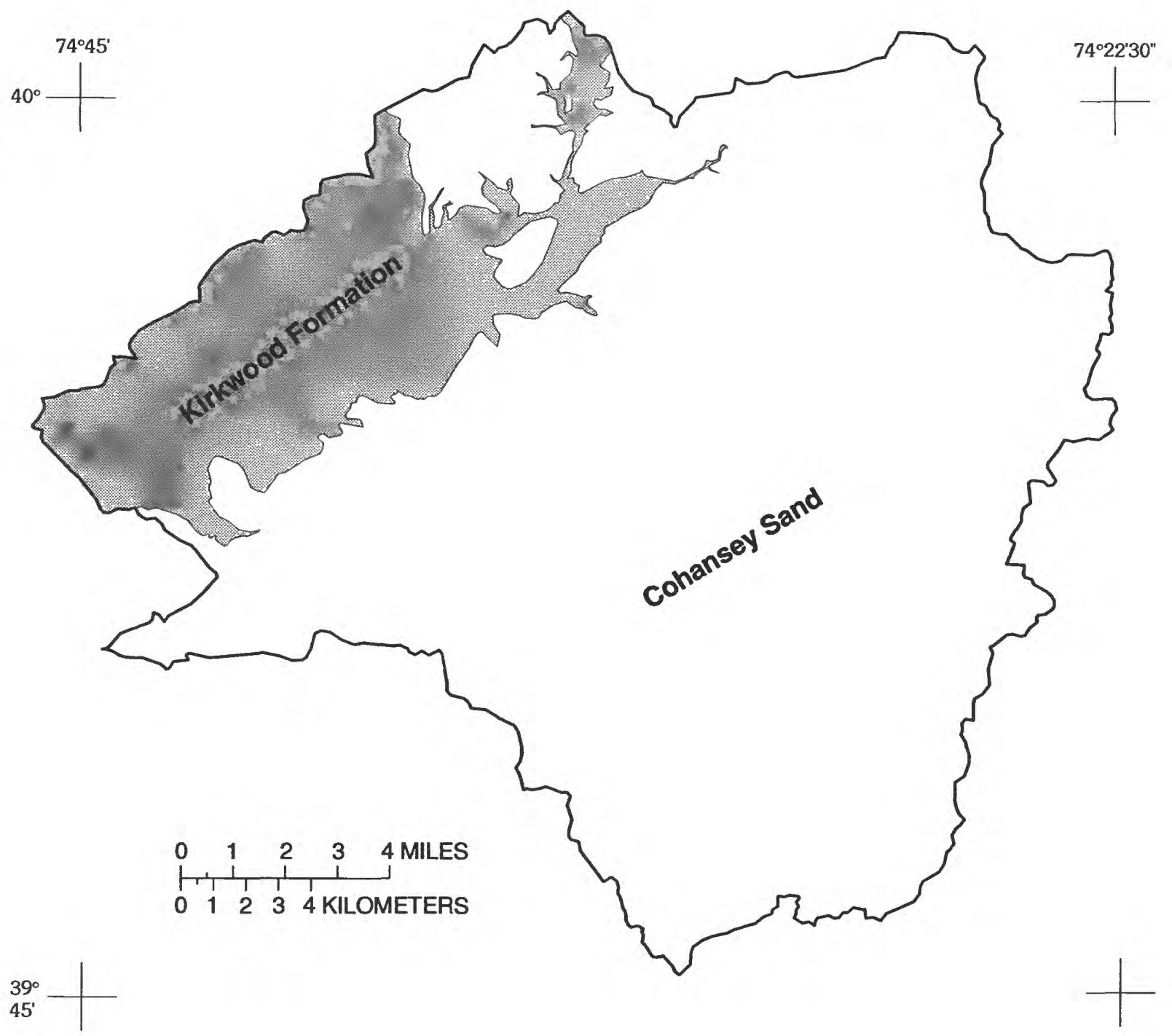

Figure 4. Areal distribution of the Cohansey Sand and the Kirkwood Formation in the modeled area, New Jersey Pinelands. 
The steady-state flow simulated in the model represents the average long-term water years (195694) recharge and discharge conditions in the upper parts of the Rancocas Creek and Wading River Basins under unstressed conditions. Recharge and evapotranspiration vary daily and seasonally, causing nearly continuous variations in flow in the system. Additional transient effects result from agricultural activities in some parts of the system, such as the West Branch Wading River located near Chatsworth (fig. 1).

\section{Conceptual Model of the Ground-Water-Elow System}

Generalized flow paths in a representative section through the ground-water-flow system in the upper Rancocas Creek Basin are illustrated in figure 5. Recharge enters the system at the land surface and moves downward toward the base of the system at the top of the confining unit. Some ground water continues to move downward through the basal Kirkwood confining unit and seeps into the Piney Point aquifer. However, most of the ground water flows horizontally away from the drainage divide, to the west and east; in the modeled area, ground water moves to the west in the updip direction. Near discharge areas, deeper ground water flows upward, mixes with shallow ground water, and seeps to local surface depressions or discharges to streams. A small amount of ground water flows upward from the underlying Vincentown aquifer.

\section{Model Design}

In this section the design of the flow model is considered. Boundary conditions, discharge to streams, and discretization are described.

\section{Boundary Conditions}

The perimeter of the modeled area is represented as a no-flow boundary. A segment of the perimeter, at the northwestern edge of the modeled area, coincides with the updip limit of the Kirkwood Formation (fig. 6). The rest of the perimeter follows the boundaries of surface-water divides. A segment of the region's major drainage divide coincides with the eastern edge of the modeled area from the northeastern corner to a point south of latitude $39^{\circ} 52^{\prime} 30^{\prime \prime}$ and then extends to the west within the modeled area. Because flow in this system is unconfined, the upper surface of the model represents the water table and its position is calculated by the model.

The lateral boundaries of the model were selected in order to allow some distance between the McDonalds Branch and Middle Branch Basins and the nearest lateral boundary of the modeled area. Because inaccuracies in numerical-flow solutions tend to be large along model boundaries, it was necessary to keep these boundaries distant from the subarea. Consequently, the model boundaries were extended to include the upper part of the Wading River Basin. Typically, it is preferable to select model boundaries that coincide with boundaries of major drainage divides when possible. Although a part of the divide is incorporated into the model boundary, the segment of the divide that extends along the southern side of the McDonalds Branch Basin was not used as a model boundary because of its proximity to the area of primary interest.

The underlying aquifers were not explicitly simulated in the model. In order to simulate the effects of seepage between the Kirkwood-Cohansey aquifer system and the underlying aquifers, the base of the ground-water-flow system is modeled as a head-dependent seepage boundary by using Modflow's General Head Boundary module (McDonald and Harbaugh, 1988). Water seeps between the Kirkwood-Cohansey aquifer system and the Piney Point aquifer and, to a lesser degree, between the Kirkwood-Cohansey 


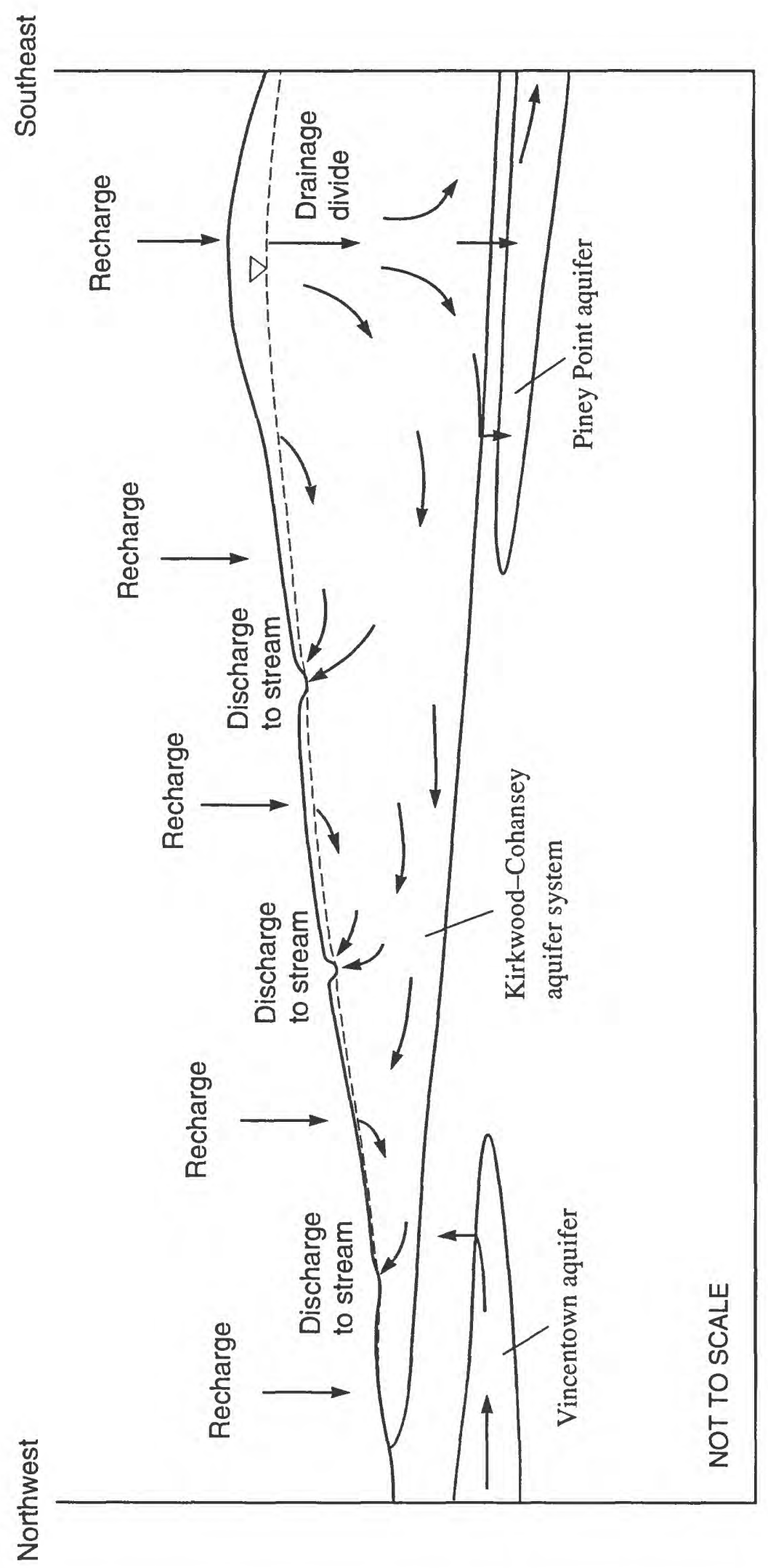

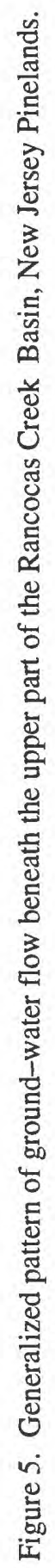




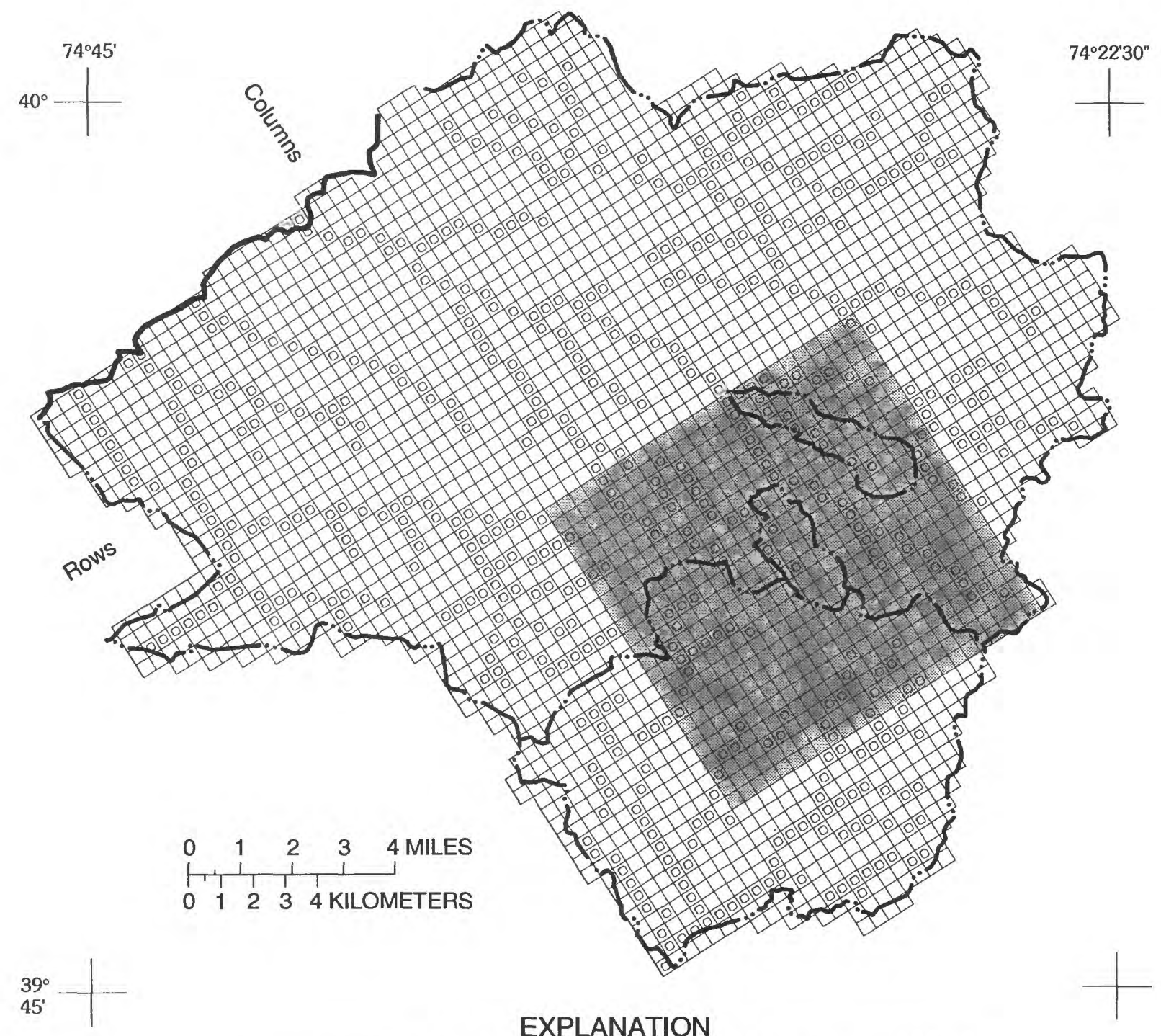

EXPLANATION

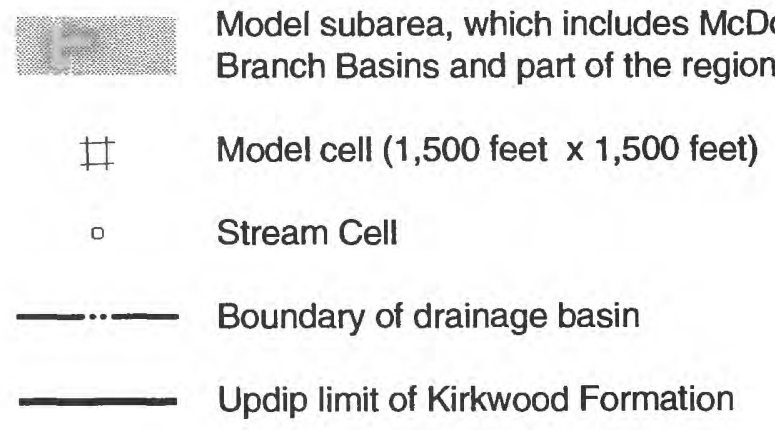

Figure 6. Horizontal discretization of aquifer and drainage network in the modeled area, New Jersey Pinelands. 
aquifer system and Vincentown aquifer. Ground-water head values for the underlying aquifers were obtained from parts of potentiometric-surface maps (Zapecza and others, 1987) of areas that overlap with the upper parts of the Rancocas Creek and Wading River Basins.

\section{Discharge to Streams}

Streams in the modeled area are effluent, as indicated by the high proportion of stream discharge that is derived from base flow. This is typical of streams in the New Jersey Coastal Plain, which are supported predominantly by discharge from the Kirkwood-Cohansey aquifer system, which consists primarily of sand. Cells used to simulate streams in the model are shown in figure 6. These cells function as sinks when heads in the aquifer are greater than the elevation of the streambed. As a result, the start-offlow location along each stream is determined as part of the flow solution.

In the basins, discharge is not necessarily restricted to stream channels but, rather, occurs over broader topographic depressions. These depressions are filled by deposits of muck that generally vary in thickness from 1 to $3 \mathrm{ft}$ (Mackey, 1971). The hydraulic interaction between ground water that discharges to swamp deposits from the underlying aquifer and streams that flow along the surface of the muck is complex. The texture of the muck varies considerably, from almost fluid when saturated to paste-like when water levels are lower. Streams commonly do not flow in well-defined channels in wet seasons, but instead form diverging and anastomosing networks around hummocks created by the bases of Atlantic White Cedars, which are common in the stream-wetland ecosystems. The scale of the model cells precludes the simulation of these small-scale flow processes. Consequently, the flux determined for cells that are used to simulate discharge to streams is a net flux through the top of the model cell -- that is, the difference between the simulated recharge and discharge.

\section{Discretization}

The horizontal division of the aquifer system and drainage network into discrete cells is shown in figure 6. The modeled part of the Kirkwood-Cohansey aquifer system is divided into two layers of evenly spaced cells that are $1,500 \mathrm{ft}$ by $1,500 \mathrm{ft}$ in size. The vertical division in a generalized section of the system from the divide to the pinchout of the Kirkwood Formation is shown in figure 7. The two lithologic components of the Kirkwood-Cohansey aquifer system are, for the most part, represented by separate model layers. For this flow simulation, the thickness of the Cohansey Sand is assumed to be two-thirds of the total aquifer thickness. The altitude of the base of the Kirkwood Formation, estimated from geophysical logs, was used to determine total aquifer thickness (Zapecza, 1989). In the aquifer system, no distinct contact or marker bed distinguishes these units; however, because the hydraulic conductivity of the Cohansey Sand is considered to be greater than that of the Kirkwood Formation, each aquifer unit is represented by a separate model layer so that each can be assigned a different conductivity value. Hydraulicconductivity values that represent composite lithologies were used for cells of the top layer located adjacent to the "contact" between the Kirkwood Formation and the Cohansey Sand.

\section{Recharge}

The average annual precipitation in the Coastal Plain of New Jersey is $45 \mathrm{in} / \mathrm{yr}$ (Rhodehamel, 1970). About half of the precipitation recharges the aquifer system; the balance is consumed in evapotranspiration and surface runoff. Extensive forests in the region account for ground-water losses to transpiration during the growing season. Evaporation also causes loss of ground water from the system, especially in areas where depth-to-water is shallow, such as near wetlands and streams. Where cranberry bogs are present, such as south of Chatsworth (fig. 1) and near the West Branch Wading River-Shoal Branch area (fig. 9, farther on), the diversion of water to flood the bogs also increases the potential evaporation. 


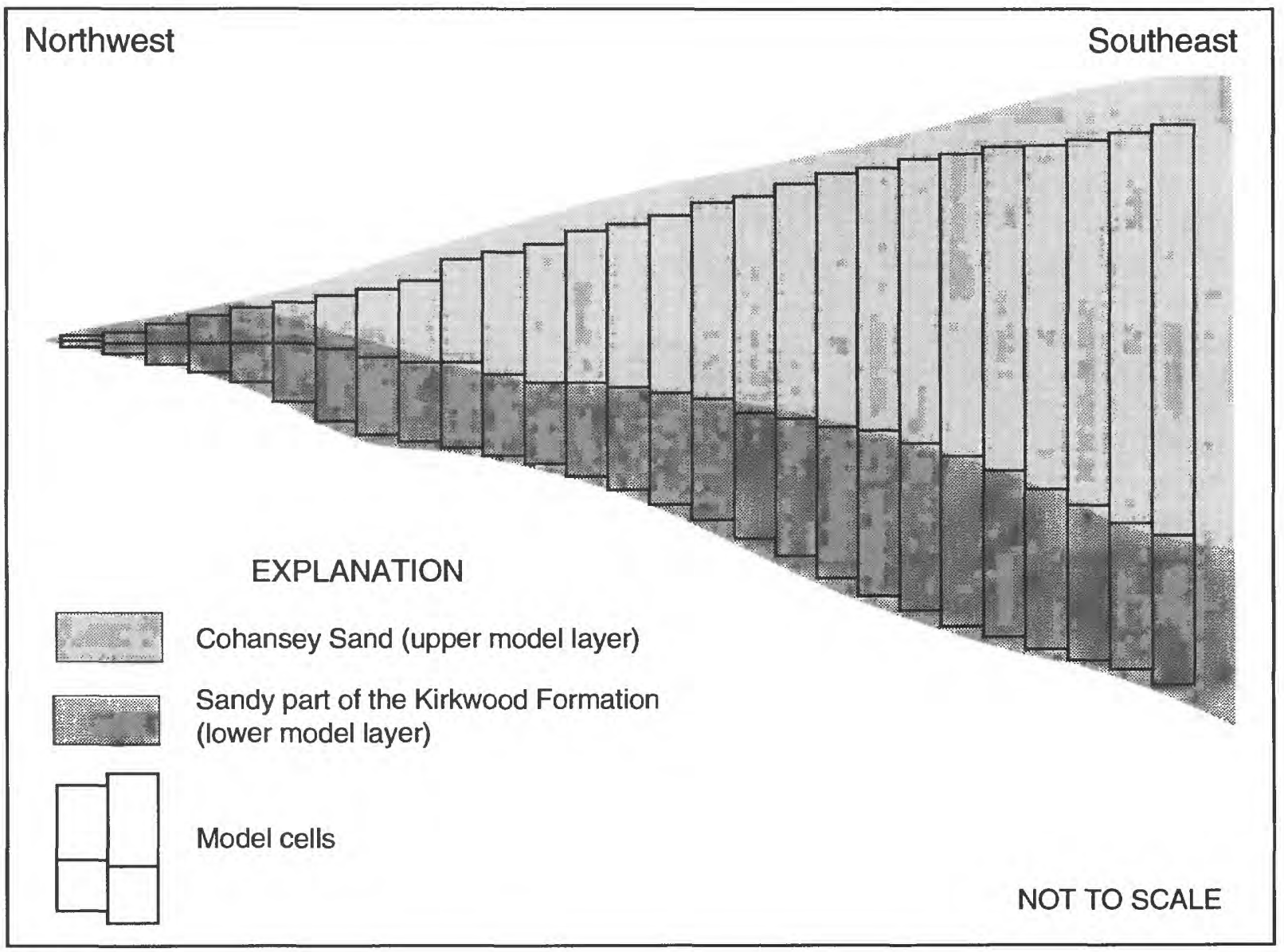

Figure 7. Vertical discretization of the ground-water-flow model and relation between aquifer units and model layers, New Jersey Pinelands. 
The amount of direct runoff generally is small but varies with soil cover and underlying sediment. Where the Cohanscy Sand is exposed, surface runoff can be as little as 6 percent of rainfall. In the western parts of the basin where the Kirkwood Formation crops out, overland flow tends to be greater than in parts where the Kirkwood Formation is not exposed. Recharge rates ranging from 15 to $20 \mathrm{in} / \mathrm{yr}$ were applied to the modeled area to reflect variations in evapotranspiration loss and runoff.

\section{Hydraulic Properties of the Kirkwood-Cohansey Aquifer System and Underlying Units}

Few aquifer tests have been conducted in the modeled area. An aquifer test was performed about $2.5 \mathrm{mi}$ south of Batsto (fig. 1) in the Mullica River Basin in 1960 to determine the effects of induced infiltration from the Mullica River on the adjacent aquifer (Lang and Rhodehamel, 1963). The transmissivity of the Kirkwood-Cohansey aquifer system was determined to be about $20,000 \mathrm{ft}^{2} / \mathrm{d}$. Although this value was thought to represent the transmissivity of the entire Kirkwood-Cohansey aquifer system, well logs from the modeled area and adjacent areas indicate that the sediments of the Cohansey Sand are coarser than those of the Kirkwood Formation (Zapecza, 1989). For this model, initial horizontal conductivity values were from 80 to $120 \mathrm{ft} / \mathrm{d}$ for the Cohansey Sand (upper model layer) and $60 \mathrm{ft} / \mathrm{d}$ for the Kirkwood Formation (lower model layer). A horizontal-to-vertical anisotropy ratio of 10:1 was assumed for each unit. The hydraulic-conductivity values used in the simulation are listed in table 1 . Conductance terms that were needed to simulate ground-water seepage across the base of the model were calculated by dividing vertical conductivities of confining units listed in table 1 by confining-unit thickness (Zapecza, 1989).

\section{Performance and Calibration Criteria}

The performance criteria used for the model require that simulated water levels be reasonably similar to measured water levels, particularly in the McDonalds-Middle Branch part of the modeled area, where observation wells are more plentiful than elsewhere. Also, simulated base flow should closely resemble base-flow values derived from measured stream discharge. Because available hydrologic data for the modeled area are limited, the model calibration criteria were not rigorous and werc limited mainly to comparisons of averages of available watcr-level and stream-discharge measurcments. Although most of the available hydrologic measurements were not taken concurrently, steady-state water levels and stream discharge can be determined from these measurements providing that they are made in an area where average long-term seasonal fluctuations in water levels are small. Water levels in a continuous-record well located in the upland area of Lebanon State Forest (fig. 1) indicate that the average minimum and maximum water levels for the water years 1956-94 varied less than $2 \mathrm{ft}$ from the average annual mean value for that period. Seasonal fluctuations in lowland areas typically are even smaller.

The water-level criterion used in model calibration was that model-calculated water levels match measured water levels within $5 \mathrm{ft}$ near the McDonalds-Middle Branch area. In the rest of the modeled area, where wells are sparse, the resemblance between the topology of the simulated and interpreted water tables should be reasonably good. A water-table map was prepared that is based, in part, on water levels in Zapecza and others (1987). In areas adjacent to streams, the water table was assumed to be near the elevation of the streambed -- generally an accurate assumption except locally where fine-grained material modifies the relations between the stream and shallow ground water. Water levels in wells screened in the shallow, unconfined aquifer close to streams near Middle Branch and McDonalds Branch are from 0.3 to $1.0 \mathrm{ft}$ higher than stream-gage height.

Simulated stream discharge was compared to streamflow records from four continuous- and one partial-record site over their respective periods of record. The streamflow-calibration criteria used in this study specify that simulated base-flow values be within 10 percent of base-flow values calculated from 
Table 1. Values of hydraulic conductivity and recharge used in groundwater-flow model simulation of the upper parts of the Rancocas Creek and Wading River Basins, New Jersey Pinelands

$$
\text { [--, not applicable] }
$$

\begin{tabular}{|c|c|c|}
\hline \multirow[b]{2}{*}{ Units } & \multicolumn{2}{|c|}{$\begin{array}{l}\text { Hydraulic conductivity } \\
\text { (feet per day) }\end{array}$} \\
\hline & Horizontal & Vertical \\
\hline \multicolumn{3}{|l|}{ Aquifer } \\
\hline \multicolumn{3}{|l|}{$\begin{array}{l}\text { Kirkwood-Cohansey aquifer } \\
\text { system: }\end{array}$} \\
\hline Upper & $80-120$ & $8-12$ \\
\hline Lower & 60 & 6 \\
\hline \multicolumn{3}{|l|}{ Confining units } \\
\hline Basal Kirkwood & -- & $2 \times 10^{-4}-5 \times 10^{-3}$ \\
\hline Vincentown-Manasquan & -- & $5 \times 10^{-4}-2.5 \times 10^{-3}$ \\
\hline Navesink-Hornerstown & -- & $3 \times 10^{-6}-3 \times 10^{-5}$ \\
\hline Recharge (inches per year): & $15-20$ & \\
\hline
\end{tabular}


\urcorner$\exists \wedge \exists\urcorner \forall \exists S \exists \wedge O 8 \forall \perp \exists \exists \exists N I ‘\urcorner \exists \wedge \exists\urcorner \mathrm{Y} \exists \perp \forall M$

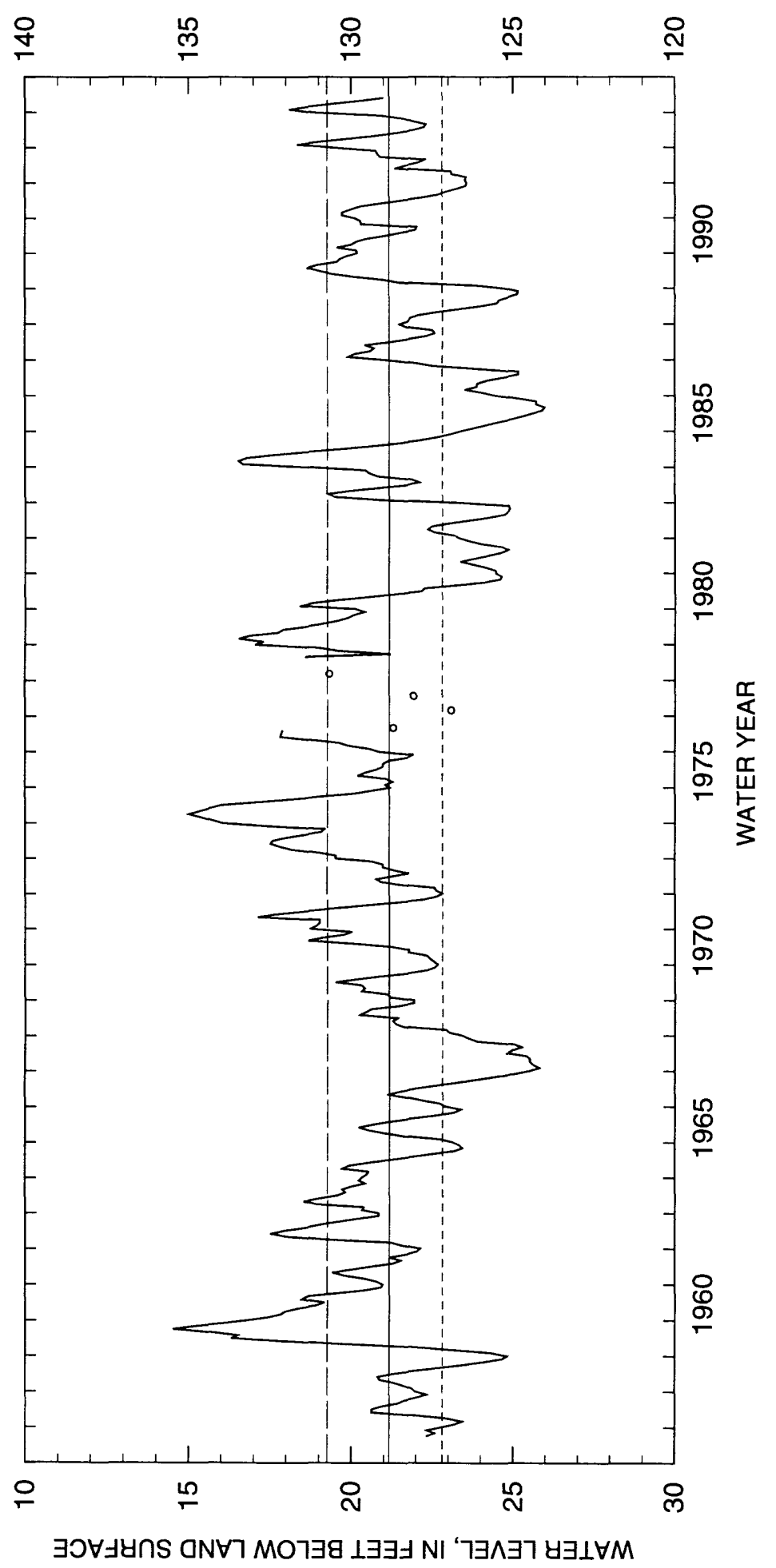

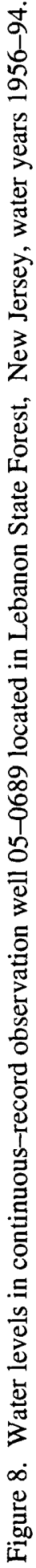


continuously measured discharge at the four stations. Base-flow values were computed by using the sliding method of hydrograph separation (Sloto, 1991). Calibration criteria for the West Branch Wading RiverShoal Branch area specify that simulated and calculated base-flow values agree to within 20 percent.

The locations of five streamflow-gaging stations in the modeled area and their associated drainage areas are shown in figure 9. Only the Pemberton and McDonalds Branch stations currently are in use. The drainage area gaged by the Vincentown station covers more than $64 \mathrm{mi}^{2}$ and extends beyond the border of the model at the northwestern edge; consequently, it was expected that simulated base flows would be lower than measured flows for this drainage area. The Pemberton station records streamflow contributed from a basin area of $118 \mathrm{mi}^{2}$, which constitutes more than one-half the modeled area. The Middle Branch and McDonalds Branch stations each record streamflow from small drainage basins of less than $3 \mathrm{mi}^{2}$. A partial-record station established in 1975 at the confluence of the West Branch Wading River and Shoal Branch records streamflow from a $45-\mathrm{mi}^{2}$ area.

Values of three model input parameters were adjusted in order to meet the calibration criteria-horizontal hydraulic conductivity of the aquifer, vertical conductance of the streambed, and rate of recharge. The adjustments of aquifer conductivity and recharge were constrained by upper and lower limiting values to ensure that the modeled system is a reasonable representation of the ground-water flow system. No limits were set for streambed conductance, however, because streambed conductance is a lumped parameter that gencrally includes the effects of the vertical hydraulic properties of the aquifer and grid discretization as well as streambed characteristics. For this simulation, the initial conductance values were computed from the model cell dimensions and aquifer vertical-conductivity values. The initial values subsequently were adjusted by trial-and-error during model calibration.

According to Rhodehamel (1973), the maximum horizontal hydraulic conductivity of the Cohansey Sand is $150 \mathrm{ft} / \mathrm{d}$. Harbaugh and Tilley (1984) used $15 \mathrm{ft} / \mathrm{d}$ as a lower limiting value for the Mullica River Basin to account for lower conductivity material in the aquifer. Aquifer-conductivity values used for the upper Rancocas Creek and Wading River Basins ground-water-flow model were within these limiting values.

Variation in recharge rate is attributed to variation in runoff and evaporation. Evaporation is greatest in topographic depressions where depth to water is least. Runoff is highest in areas where the land surface is composed of relatively impermeable material. A higher rate of runoff is assumed in areas where the lower part of the Kirkwood Formation crops out or underlies other deposits than in areas where the Cohansey Sand crops out. A recharge rate of $20 \mathrm{in} / \mathrm{yr}$ is assumed to be the maximum value and reflects a small amount of runoff and average evapotranspiration. A recharge rate of $15 \mathrm{in} / \mathrm{yr}$ was designated as a lower limit and incorporates the assumption that surface runoff and (or) evapotranspiration are more significant.

\section{Calibration Results}

The interpreted and simulated water-table surfaces are shown in figure 10. In general, the match is considered satisfactory; the two sets of contour lines generally coincide, indicating that the interpreted and simulated water-table surfaces are similar. In a few areas, however, the contour lines match less similar, especially near the lateral boundaries of the model. Because the assumption that model hydrologic boundaries coincide with physiographic boundaries is not always valid, simulation results near model boundaries must be interpreted with caution.

Simulated ground-water heads in cells closest to well locations were compared with heads measured in wells. Water levels measured in wells in the modeled area that were used for calibration are listed in table 2 and shown in figure 11 . The average measured head value, the corresponding simulated head 


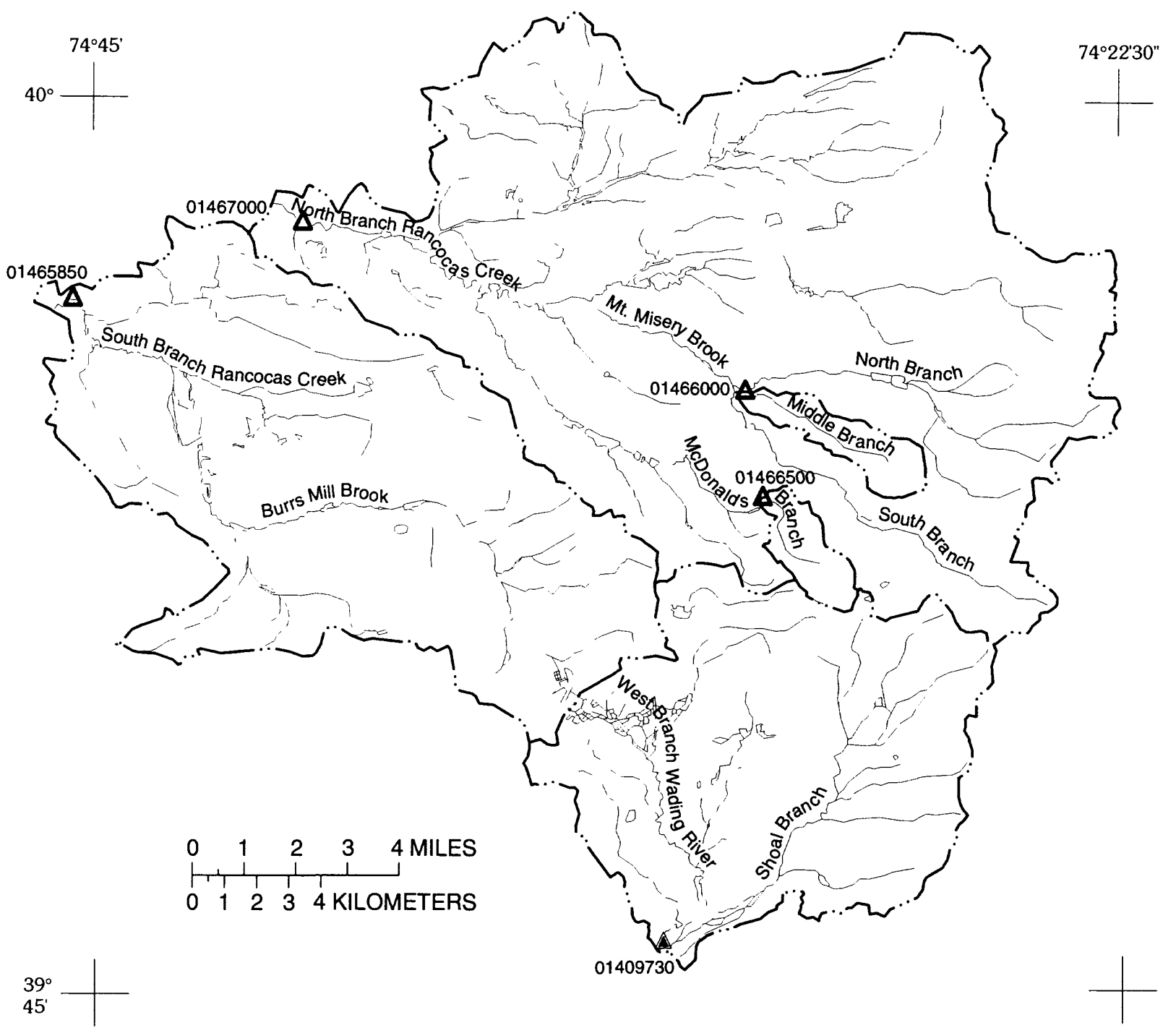

\section{EXPLANATION}

—.. Boundary of drainage basin

$01402720 \Delta$ Continuous-record gaging station and number

$01409730 \Delta \quad$ Low-flow partial-record station and number

Figure 9. Locations of drainage basins and streamflow-gaging stations in the modeled area, New Jersey Pinelands. 
value, and the difference between the two are listed for each well. Simulated heads near wells in the McDonalds-Middle Branch area generally are within the 5-ft water-level calibration criterion. The mean absolute error of the difference between measured and simulated heads for all the wells is $3.2 \mathrm{ft}$.

A list of average measured stream-discharge values and simulated base-flow values for each of the streamflow-gaging stations used in the study is given in table 3. Calculated base-flow values also are listed for continuous-record stations. The periods of record for the stations are not concurrent but overlap for some stations.

Simulated base-flow values match closely with base-flow values calculated from measured streamflow. Base flow is a smaller component of streamflow at the South Branch Rancocas Creek at Vincentown station (01465850) than at the other three continuous-record gaging stations. This may indicate that direct runoff is a larger component of streamflow in the South Branch Rancocas Creek drainage basin than in the other basins, possibly as a result of lower permeability of the soil and aquifer material adjacent to the South Branch Rancocas Creek. This may be related to the outcrop of the Kirkwood Formation occupying a larger part of this basin than of adjacent basins.

Because the periods of record for the continuous-record stations listed in table 3 are not concurrent, streamflow data also were arranged into two concurrent periods; as a result, not all available data were used. Values of simulated and calculated base flow at the stations for those periods for which concurrent streamflow data are available are shown in table 4. For the South Branch Rancocas Creek at Vincentown station for the 1962-76 period, simulated base flow was within 11 percent of calculated base flow. For all other stations for both periods, simulated base flows were within 4 percent of calculated base flows.

The match between discharge calculated from low-flow partial records for the West Branch Wading River near Chatsworth station (01409730) and simulated base flow at that station was relatively poor (table 3). The model may overestimate discharge in this area because the no-flow boundaries near the Shoal Branch and West Branch Wading River do not permit deep ground-water flow between upland recharge areas and discharge locations downstream from the modeled area. Another source of error may be related to the concentration of cranberry agriculture in the West Branch Wading River area. Because of the frequent damming of stream water by means of sluices and artificial impoundments, stage measurements made downstream may have been lower than normal.

\section{CHARACTERISTICS OF UNSTRESSED, STEADY-STATE FLOW IN THE UPPER RANCOCAS CREEK AND WADING RIVER BASINS}

In this section, the ground-water flow budget, flow velocity, residence times, and flow patterns in the modeled system are discussed. The source areas of ground-water flow to streams and to the underlying Piney Point aquifer within a subarea of the model also are considered.

\section{Regional Flow Budget}

The simulated ground-water budget for the modeled aquifer system for unstressed conditions is shown in table 5. Although simulated values may not correspond to those of the ground-water system, the relative proportions appear to be consistent with the conceptual model of the flow system. Recharge is the dominant source of ground water to the system and accounts for more than 98 percent of the budget inflow. Water that seeps into the system from the underlying Vincentown aquifer and surface-water bodies are minimal components of inflow. Almost 92 percent of the ground water leaves the system as discharge to streams and other surface-water bodies. A relatively small but quantitatively significant component of ground-water flow (8.1 percent) seeps into the Piney Point aquifer. 


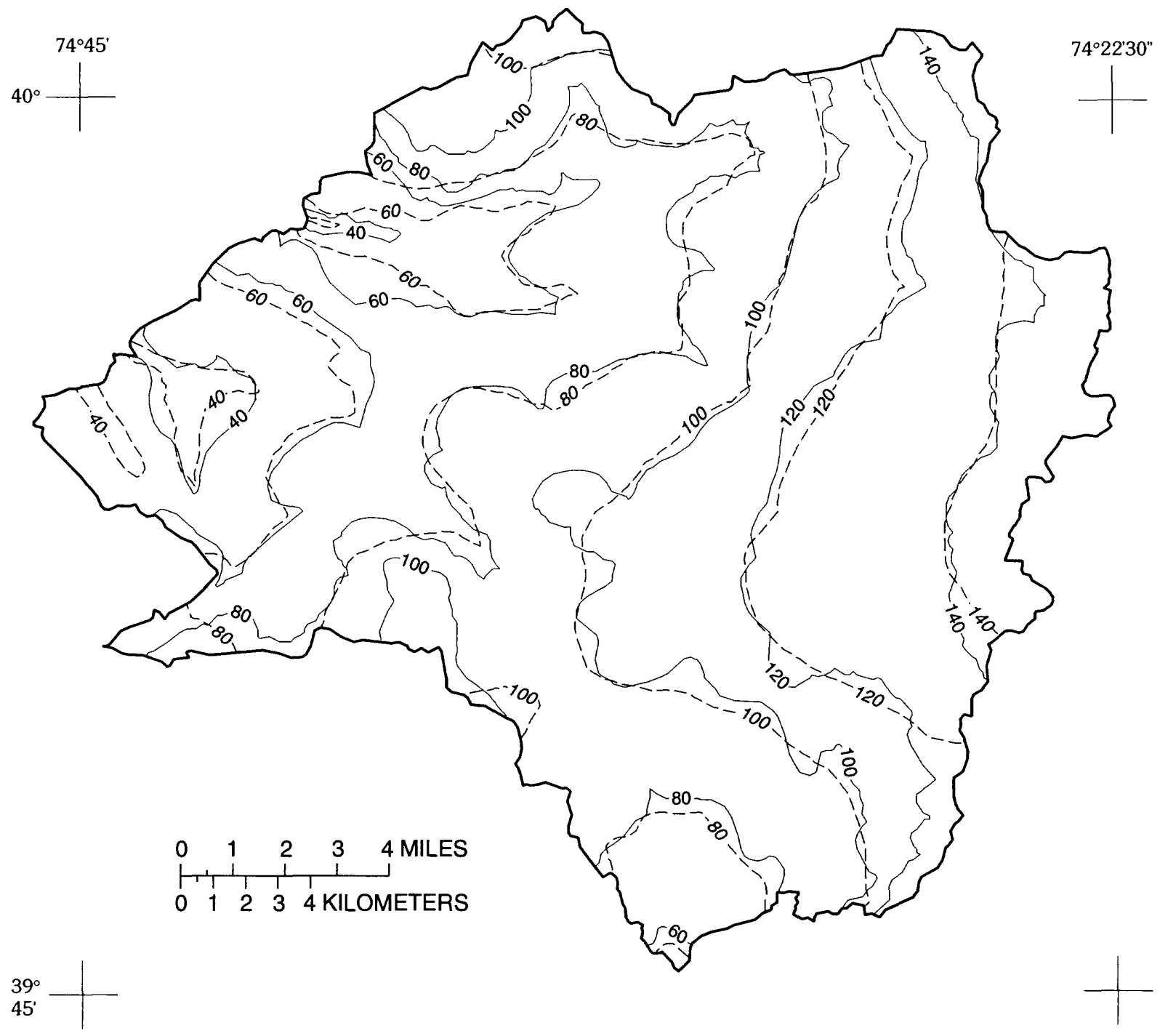

EXPLANATION

Boundary of modeled area

- - - $100----$ Simulated water-table contour. Contour interval 20 feet

$-100-$ Interpreted water-table contour. Contour interval 20 feet

Figure 10. Simulated and interpreted water-table contours in the modeled area, New Jersey Pinelands. 
Table 2. Average measured water levels in wells and simulated head values for corresponding model cells, New Jersey Pinelands

[Well locations are shown in fig. 11]

\begin{tabular}{|c|c|c|c|}
\hline \multirow[b]{2}{*}{ Well number } & \multicolumn{3}{|c|}{$\begin{array}{c}\text { Water level } \\
\text { (feet above sea level) }\end{array}$} \\
\hline & $\begin{array}{c}\text { Observed } \\
\text { average 1955- } \\
93\end{array}$ & Simulated & Difference $^{1}$ \\
\hline $05-0689$ & 130.4 & 130.5 & -0.1 \\
\hline $05-1074$ & 134.8 & 130.9 & 3.9 \\
\hline 05-0905 & 120.4 & 118.4 & 2.0 \\
\hline 05-0897 & 126.4 & 124.9 & 1.5 \\
\hline $05-0709$ & 105.0 & 107.2 & -2.2 \\
\hline 05-0708 & 114.0 & 114.1 & -.1 \\
\hline $05-0690$ & 116.8 & 117.2 & -.4 \\
\hline $05-0684$ & 121.1 & 121.1 & .0 \\
\hline $29-0772$ & 131.2 & 129.3 & 1.9 \\
\hline $05-0678$ & 94.3 & 97.5 & -3.2 \\
\hline $05-0674$ & 89.3 & 93.2 & 3.9 \\
\hline $05-0693$ & 93.0 & 93.5 & -.5 \\
\hline $05-0692$ & 103.0 & 98.3 & 4.7 \\
\hline $05-0357$ & 104.0 & 111.2 & -7.2 \\
\hline $05-1120$ & 83.8 & 85.1 & -1.3 \\
\hline $05-0865$ & 131.8 & 126.0 & 5.8 \\
\hline $05-0727$ & 100.5 & 87.3 & 13.2 \\
\hline $05-0698$ & 128.8 & 128.2 & .6 \\
\hline $29-0755$ & 115.7 & 107.2 & 8.5 \\
\hline $05-1142$ & 106.3 & 106.1 & .2 \\
\hline $05-1141$ & 82.8 & 77.1 & 5.6 \\
\hline
\end{tabular}

${ }^{1}$ Mean absolute error $=3.2$ feet 


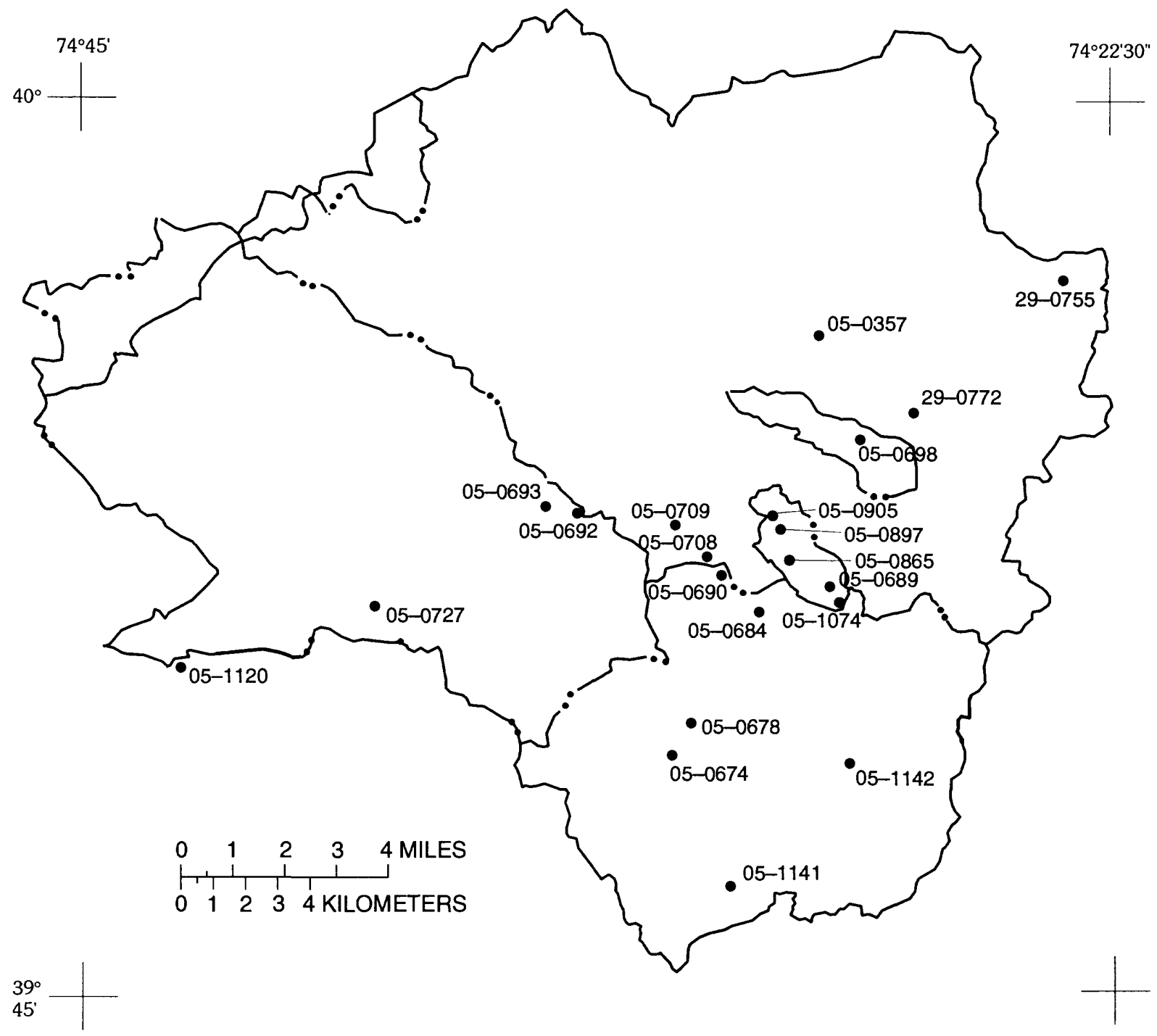

\section{EXPLANATION}

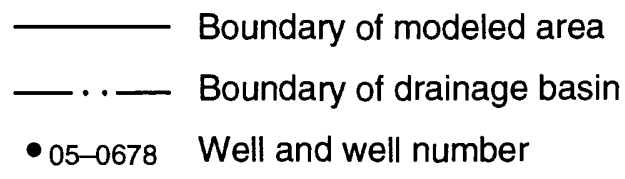

Figure 11. Locations of wells in the modeled area used to calibrate the ground-water-flow model, New Jersey Pinelands. 
Table 3. Measured streamflow, calculated base flow, and simulated base flow at continuous- and partial-record gaging stations in the modeled area, New Jersey Pinelands

[ft $\mathrm{ft}^{3} / \mathrm{s}$, cubic feet per second; $\mathrm{mi}^{2}$, square miles; --, not applicable]

\begin{tabular}{|c|c|c|c|c|c|c|}
\hline $\begin{array}{l}\text { Streamflow- } \\
\text { gaging sta- } \\
\text { tiom name } \\
\text { and number }\end{array}$ & Station type & $\begin{array}{r}\text { Drainage } \\
\text { area } \\
\left(\mathrm{mi}^{2}\right)\end{array}$ & $\begin{array}{l}\text { Period of } \\
\text { record }\end{array}$ & $\begin{array}{r}\text { Average } \\
\text { measured } \\
\text { streamflow } \\
\left(\mathrm{ft}^{3} / \mathrm{s}\right)\end{array}$ & $\begin{array}{r}\text { Calculated } \\
\text { base flow } \\
\left(\mathrm{ft}^{3} / \mathrm{s}\right)\end{array}$ & $\begin{array}{r}\text { Simulated } \\
\text { base flow } \\
\left(\mathrm{ft}^{3} / \mathrm{s}\right)\end{array}$ \\
\hline $\begin{array}{l}\text { McDonalds } \\
\text { Branch in } \\
\text { Lebanon State } \\
\text { Forest, N. J. } \\
01466500\end{array}$ & $\begin{array}{l}\text { Continuous- } \\
\text { record }\end{array}$ & 2.35 & $1954-90$ & 2.23 & 2.05 & 2.07 \\
\hline $\begin{array}{l}\text { Middle } \\
\text { Branch-Mt. } \\
\text { Misery Brook } \\
\text { in Lebanon } \\
\text { State Forest, } \\
\text { N. J. } \\
01466900\end{array}$ & $\begin{array}{l}\text { Continuous- } \\
\text { record }\end{array}$ & 2.82 & $\begin{array}{c}1953-65 \\
1977\end{array}$ & 1.93 & 1.65 & 1.69 \\
\hline $\begin{array}{l}\text { North Branch } \\
\text { Rancocas } \\
\text { Creek at Pem- } \\
\text { berton, N. J. } \\
01467060\end{array}$ & $\begin{array}{l}\text { Continuous- } \\
\text { record }\end{array}$ & 118.00 & $1922-90$ & 171.34 & 136.85 & 135.08 \\
\hline $\begin{array}{l}\text { South Branch } \\
\text { Rancocas } \\
\text { Creek at Vin- } \\
\text { centown, N. J. } \\
01465850\end{array}$ & $\begin{array}{l}\text { Continuous- } \\
\text { record }\end{array}$ & 64.50 & $1962-76$ & 95.98 & 69.33 & 73.50 \\
\hline $\begin{array}{l}\text { West Branch } \\
\text { Wading River } \\
\text { near Chat- } \\
\text { sworth, N. J. } \\
01409730\end{array}$ & $\begin{array}{l}\text { Partial- } \\
\text { record }\end{array}$ & 44.80 & $1975-77$ & 49.74 & -- & 59.00 \\
\hline
\end{tabular}

1 Determined by using the sliding method of hydrograph separation (Sloto, 1991) 
Table 4. Measured streamflow, calculated base flow, and simulated base flow grouped into concurrent periods of record at continuous-record gaging stations in the modeled area, New Jersey Pinelands

$\left[\mathrm{ft}^{3} / \mathrm{s}\right.$, cubic feet per second]

\begin{tabular}{|c|c|c|c|}
\hline $\begin{array}{l}\text { Streamflow-gaging station } \\
\text { name and number }\end{array}$ & $\begin{array}{c}\text { Average } \\
\text { measured } \\
\text { streamflow } \\
\left(\mathrm{ft}^{3} / \mathrm{s}\right)\end{array}$ & $\begin{array}{l}\text { Calculated base } \\
\text { flow } \\
\left(\mathrm{ft}^{3} / \mathrm{s}\right)\end{array}$ & $\begin{array}{c}\text { Simulated base } \\
\text { flow } \\
\left(\mathrm{ft}^{3} / \mathrm{s}\right)\end{array}$ \\
\hline \multicolumn{4}{|l|}{ 1954-65 period: } \\
\hline $\begin{array}{l}\text { McDonalds Branch in Lebanon } \\
\text { State Forest, N. J. } 01466500\end{array}$ & 2.25 & 2.09 & 2.07 \\
\hline $\begin{array}{l}\text { Middle Branch-Mt. Misery Brook } \\
\text { in Lebanon State Forest, N. J. } \\
01466900\end{array}$ & 1.93 & 1.65 & 1.69 \\
\hline $\begin{array}{l}\text { North Branch Rancocas Creek at } \\
\text { Pemberton, N. J. } 01467060\end{array}$ & 172.39 & 141.05 & 135.08 \\
\hline \multicolumn{4}{|l|}{ 1962-76 period: } \\
\hline $\begin{array}{l}\text { South Branch Rancocas Creek at } \\
\text { Vincentown, N. J. } 01465850\end{array}$ & 90.46 & 65.51 & 73.50 \\
\hline $\begin{array}{l}\text { McDonalds Branch in Lebanon } \\
\text { State Forest, N. J. } 01466500\end{array}$ & 2.30 & 2.13 & 2.07 \\
\hline $\begin{array}{l}\text { North Branch Rancocas Creek at } \\
\text { Pemberton, N. J. } 01467060\end{array}$ & 174.45 & 140.54 & 135.08 \\
\hline
\end{tabular}

${ }^{1}$ Determined by using the sliding method of hydrograph separation (Sloto, 1991) 


\section{Ground-Water Velocity}

The horizontal and vertical components of ground-water velocity can be calculated in any model cell by dividing the flow between model cells (dimensions of $\mathrm{L}^{3} / \mathrm{T}$ ) by the intercell area. The horizontal components of flow between model cells in the upper model layer are represented by velocity vectors in figure 12. The vector field defines the relative ground-water-flow velocities and directions in map view. In general, the vectors indicate that horizontal flow directions and magnitudes within the upper model layer vary considerably. Ground-water velocities tend to increase near streams; the vectors converge and increase in length approaching the stream systems. However, velocities also are high in some interstream zones to the north and west of the North Branch Rancocas Creek area and in the West Branch Wading River area to the south. Low velocities are characteristic of the South Branch area where the Kirkwood Formation crops out. Horizontal flow components are small or negligible near most of the lateral model boundaries. In these areas flow between model cells in the vertical direrction is much greater than the flow between model cells in the horizontal direction.

Because the surface-water divide is irregular, flow patterns in basins adjacent to the divide are complex. East of McDonalds Branch Basin, velocity vectors cross the divide into the West Branch Wading River-Shoal Branch area. West of McDonalds Branch Basin, velocity vectors tend to diverge near the divide, bifurcating along it to flow toward either the West Branch Wading River-Shoal Branch area or to the McDonalds-Middle Branch area, as shown in figure 12. Flow directions adjacent to the divide range from west to southwest over a relatively short distance. The directions of ground-water flow beneath McDonalds Branch Basin vary considerably because of the proximity of the basin to the divide. The vectors traverse the long axis of McDonalds Branch Basin but are oriented parallel to the long axis of Middle Branch Basin.

\section{Ground-Water Residence Time}

Ground-water residence time is the period during which ground water remains in the aquifer between the moment it enters the system as recharge and the moment it leaves as discharge. The concept of ground-water residence time is applicable to studies in which the time required to "flush out" conservative constituents that are introduced into the aquifer system is determined. It is also important in understanding the evolution of certain chemical species along flow paths within the aquifer.

The time required for a particle to move completely through the aquifer is calculated readily from the intercell flow that is used to calculate flow paths by use of a particle-tracking algorithm (Pollock, 1989). Simulated lines of equal residence time for ground water in the modeled area under unstressed conditions are shown in figure 13. The map indicates the time required for recharge entering the system at a given point on the water table to move completely through the aquifer system. The maximum time is about 200 years. (The travel time of ground water in stagnation zones or along no-flow boundaries can be extremely large.) The residence time of ground water that flows to a stream is relatively shorter than the residence time of ground water in other parts of the system. Within the source areas of flow to streams, residence times generally are 20 years or less, which indicates that the streams shorten the time that ground water remains in the system. Residence times are significantly longer in areas near the major drainage divide, however. Residence times also are longer in the source area of flow to the Piney Point aquifer, which indicates that the travel time of ground water that flows to the bottom of the aquifer is long. As will be discussed farther on, flow paths in the Piney Point aquifer diverge along their course from the source area at the water table to the seepage area at the base of the aquifer; consequently, flow velocities diminish with depth. 
Table 5. Simulated ground-water budget for the ground-water-flow model of the upper parts of the Rancocas Creek and Wading River Basins, New Jersey

Pinelands

\begin{tabular}{lcc}
\hline & \multicolumn{2}{c}{ Flow } \\
\cline { 2 - 3 } & $\begin{array}{c}\text { Percentage of } \\
\text { Ground-water-budget component }\end{array}$ & $\begin{array}{c}\text { Volumetric flow rate } \\
\text { (million gallons per day) }\end{array}$ \\
\cline { 2 - 3 } In: & 0.5 & 1.1 \\
$\quad \begin{array}{l}\text { Flow from surface-water } \\
\text { bodies }\end{array}$ & & \\
$\quad$ Recharge & 98.3 & 195.3 \\
$\quad \begin{array}{l}\text { Leakage from underlying } \\
\text { aquifer }\end{array}$ & 1.2 & 2.4 \\
Out: & & \\
$\quad$ Flow to surface-water bodies ${ }^{1}$ & 4.6 & 9.2 \\
$\quad$ Flow to streams & 87.3 & 173.5 \\
$\quad$ Leakage to underlying aquifer & 8.1 & 16.1 \\
\hline
\end{tabular}

${ }^{1}$ Other than streams 


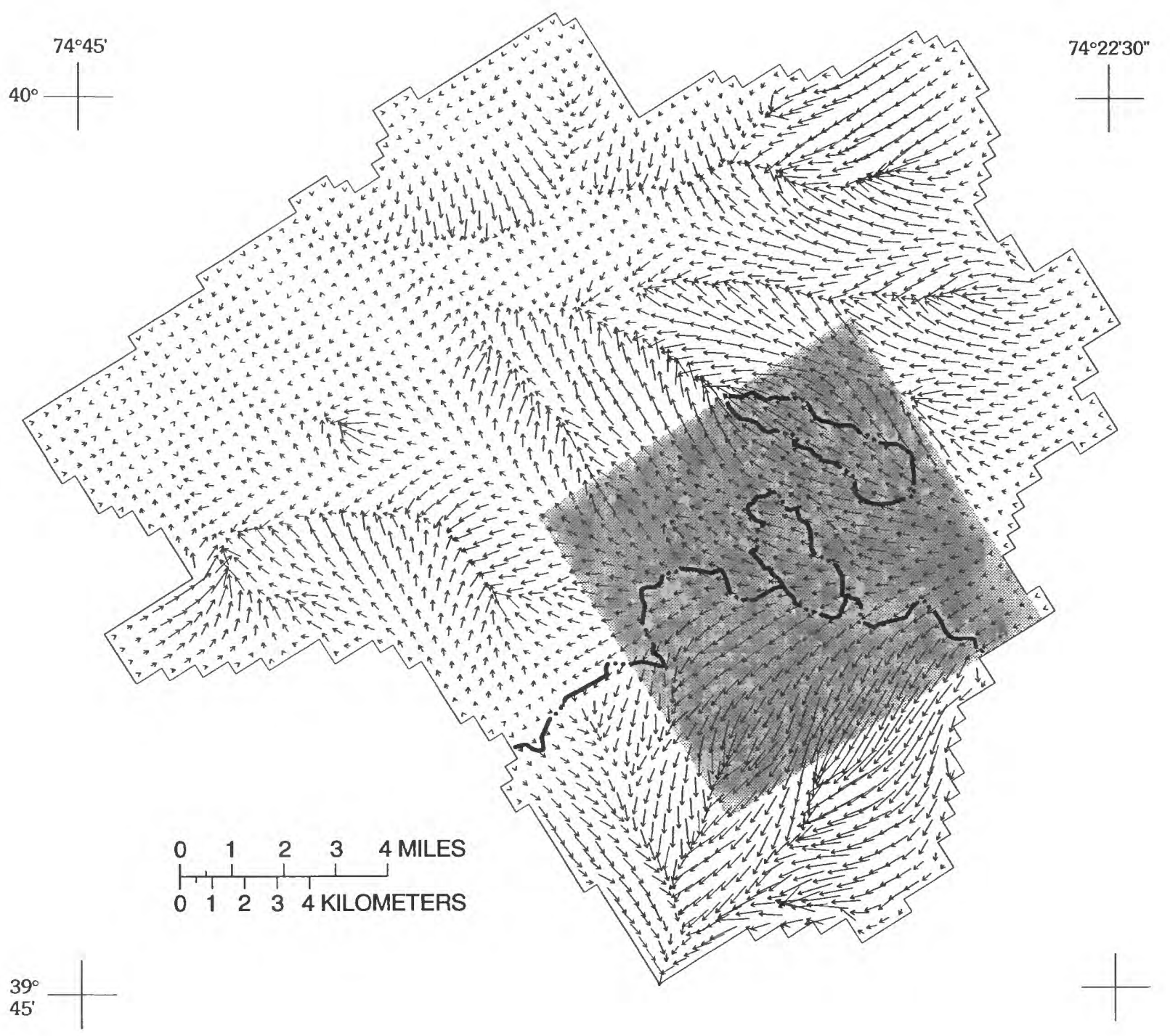

EXPLANATION

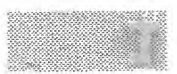

Model subarea, which includes McDonalds and Middle

Branch Basins and part of the regional drainage divide

_.._ Boundary of drainage basin

Ground-water-velocity vector indicating horizontal direction and velocity magnitude; vectors shown represent velocities ranging from $2.21 \times 10^{-5}$ feet per day to $2.94 \times 10^{-1}$ feet per day

Figure 12. Simulated horizontal ground-water-velocity vectors in the upper layer of the ground-water-flow model of the upper parts of the Rancocas Creek and Wading River Basins, New Jersey Pinelands. 
Because streams function as line-sinks for ground water, lines of equal residence time are parallel to stream channels, and ground water is progressively younger with proximity to the stream. Yet the 20year residence-time contour lines cross simulated stream channels at several places in the modeled area (fig. 13). This pattern is caused, to some degree, by coarse discretization of the stream channels into "strings" of cells, which can result in uneven discharge along the string. Discharge in some of these cells can be small or considered negligible, resulting in an interruption in discharge at points along a simulated stream channel.

Because hydraulic conductivity of the aquifer is lower in the vertical direction than in the horizontal direction, ground water that travels predominantly in the vertical direction moves more slowly than ground water that travels in a horizontal direction. Flow to streams tends to remain in the shallow part of the ground-water system and to travel predominantly in the horizontal direction; therefore, much of the water that discharges to streams is associated with short residence times.

Ground-water residence time is affected, to a large degree, by aquifer thickness. The length of a ground-water-flow path and, consequently, the associated travel time increases with the thickness of the aquifer. Simulated flow paths of particles located in column 42 of the modeled area are shown in figure 14. The flow paths were generated by assigning three particles per cell along the column at the upper boundary of the cells, and the locations of the 20 - and 80 -year travel times for the flow paths were determined. The positions of the flow paths and travel times were projected to a map view and to a vertical section parallel to the model column. The length of the flow paths increases with aquifer thickness along the column. Only the longer flow paths reach travel times of 80 years or more; they are located in the divide area, where the aquifer is thickest. The time symbols collectively demarcate "lines" of equal age. In some areas these "lines" are discontinuous as a result of the absence of ground water with an associated travel time greater than or equal to 20 (or 80 ) years.

\section{Source Areas of Flow in the McDonalds-Middle Branch Basins Area}

The McDonalds-Middle Branch Basin area is a focus of this study because (1) water-level and streamflow data are available for the area, (2) the additional hydrologic insight would enhance the usefulness of previous hydrologic studies of the area, and (3) ground-water flow in the aquifer subsystem is sensitive to conditions elsewhere in the aquifer system as a result of its location near the regional drainage divide and overlying the Piney Point aquifer; therefore, relations between small-scale basins and the larger aquifer systems are well exemplified.

Results of a particle-tracking simulation that shows the points of origin of flow paths that constitute the source areas of flow to streams located within a 48.4- $\mathrm{mi}^{2}$ area of the model under unstressed conditions are shown in figure 15. (The names of the tributaries are shown in fig. 16.) The source areas were generated by assigning an array of 16 particles to the top of each cell. Consequently, each endpoint represents one-sixteenth of the distributed recharge rate per cell, or about $730 \mathrm{ft}^{3} / \mathrm{d}$. The source area of ground water that travels to the Piney Point aquifer also is shown. "Blank" areas represent the source areas of flow to streams in the system that are located beyond the subarea. The source areas of flow to stream segments of different orders and to the Piney Point aquifer are differentiated.

The term "stream order," as used in this report, refers to the magnitude of a stream segment relative to that of other stream segments that form a drainage network (Strahler, 1952). Each stream segment within a basin is assigned an order that indicates its relative importance in the network. A stream segment is the basic ordered unit. The lowest order stream segments correspond to the most minor tributaries, 


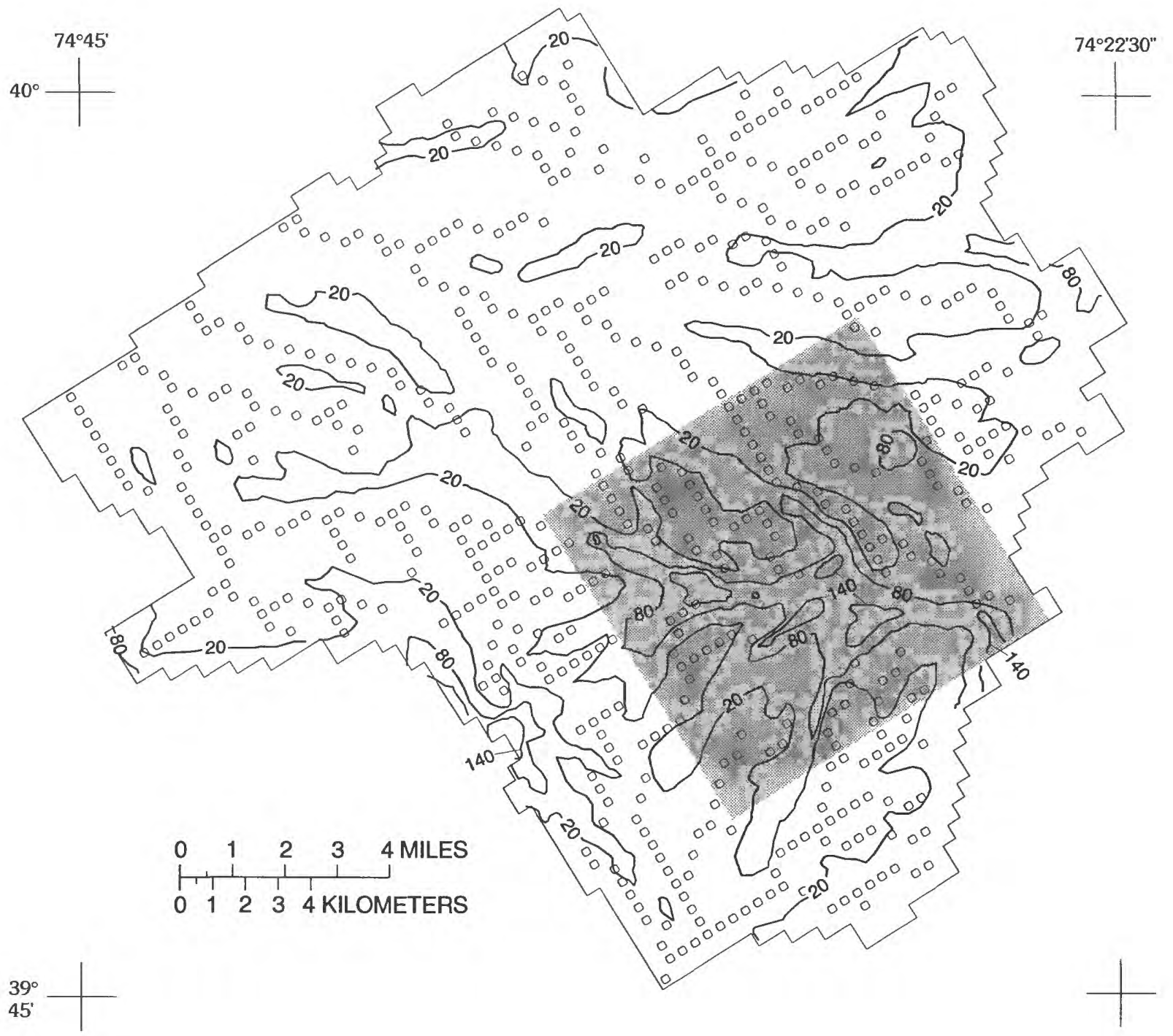

EXPLANATION

Model subarea, which includes McDonalds and Middle

Branch Basins and part of the regional drainage divide

- Stream cell $-80-\quad \begin{aligned} & \text { Line of } \\ & 60 \text { feet }\end{aligned}$

Line of equal residence time, in years. Contour interval

Figure 13. Simulated residence time of ground water in recharge areas at the water table in the ground-water-flow model of the upper parts of the Rancocas Creek and Wading River Basins, New Jersey Pinelands. 

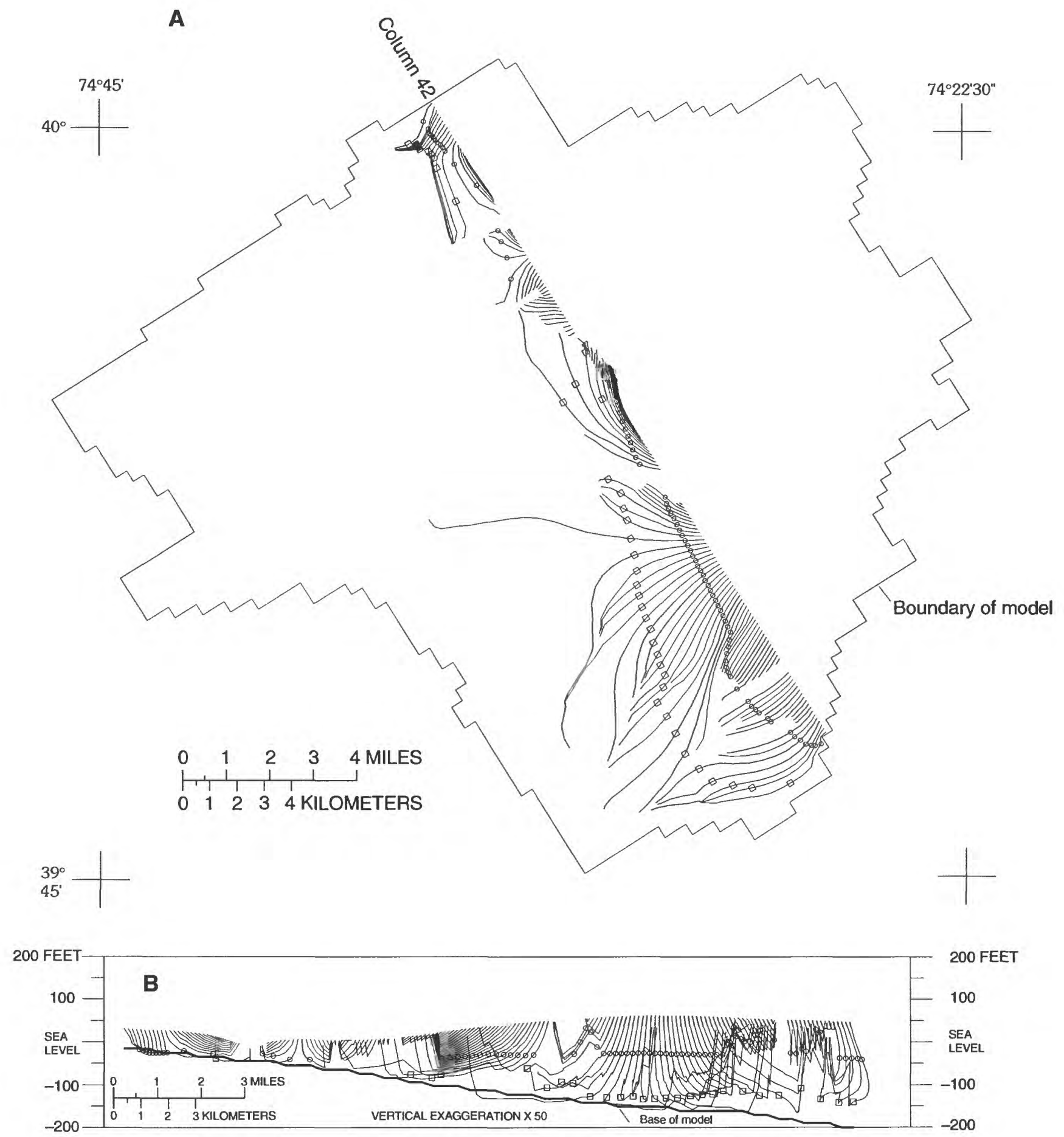

\section{EXPLANATION}

Flow path
$\therefore \quad$ Location of 20 years of travel time
$\square \quad$ Location of 80 years of travel time

Figure 14. Simulated flow paths and travel times of particles in (A) map view and (B) cross-sectional view in column 42 of the ground-water-flow model of the upper parts of the Rancocas Creek and Wading River Basins, New Jersey Pinelands. 
whereas the highest order stream segments correspond to the major trunk streams or rivers. When two lower order stream segments join, they form a stream segment of the next higher order. For example, a third-order stream segment is formed at the confluence of two second-order streams.

Simulated stream segments are shown as strings of circles in figure 15. Each circle represents the center of a cell that functions as a drain. Simulated stream segments do not correspond exactly to the mapped streams (figs. 15 and 16). In some cases, it was necessary to represent two streams with a single simulated stream segment because of the relatively large size of the model cells (for example, Gates and Reeds Brooks; see fig. 16).

The simulated source areas of flow to the stream segments that represent Gates and Reeds Brooks, shown to the west of McDonalds Branch Basin just south of the divide in figure 15, indicate that the source areas of flow to the second-order stream segment surround the source areas of flow to the first-order stream segment. A particle of ground water that originates at the upstream end of the source area of flow to this stream segment would terminate farther downstream than would any other particle in the source area. Recharge that originates in this upstream area travels deeper into the aquifer and farther than recharge from the first-order part of the Gates and Reeds Brooks source area. The first-order source area is "nested" within the second-order source area. The source area of flow to South Branch (northeast of McDonalds Branch Basin) has a similar "nested" configuration except that the higher-order component of the source area is a discontinuous band of endpoints around the lower-order component.

The recharge area of the basin forms a "mosaic" of source areas of ground-water flow that discharges to different parts of the stream network. Because the modeled system is thickest near the divide, ground water that originates there can flow deeper into the aquifer than ground water that originates in parts of the aquifer that are relatively thin. Some of this ground water seeps into the underlying Piney Point aquifer. However, most ground water that travels deep into the system flows beneath the local, shallowflow systems and moves toward the surface in a more distant part of the aquifer. Consequently, some ground water that originates in source areas near the divide is lost to the uppermost basins in the modeled system but is gained by basins located farther downstream.

Flow diverges away from the divide over a range of directions from west to south (fig. 12). This trend is also evident in the varying orientations and "bending" of the stream-source areas. Additionally, these areas are unevenly apportioned around the stream channels, as can be seen in the source areas of flow to the South and Middle Branch channels. The asymmetric distribution of the source areas around streams can be attributed, in part, to the varying proximity of neighboring streams and to the irregular parts of land area between streams that capture recharge. Although a drainage pattern develops in response to heterogeneities in aquifer material and landform, only the effect of the established stream channel on ground-water flow beneath the basin is simulated in the model. Local variations in aquifer material are not represented in the model.

Some of the configurations of source areas shown in figure 15 demonstrate that source areas of flow to low-order streams do not necessarily coincide with the physiographic borders of the basins associated with their streams. In McDonalds Branch Basin, for example, the source area of flow to McDonalds Branch extends beyond the northern boundary of the basin but is absent from the western part of the basin. Ground-water flow to Coopers Branch and Gates Branch, however, can be traced to recharge areas that lie partly within McDonalds Branch Basin. Also, a strip of the source area of flow to the Piney Point aquifer lies in McDonalds Branch Basin. These relations indicate that the locations of physiographic boundaries are more closely related to the determination of surface runoff than to source areas of ground-water flow to streams at the first-order-basin scale. 


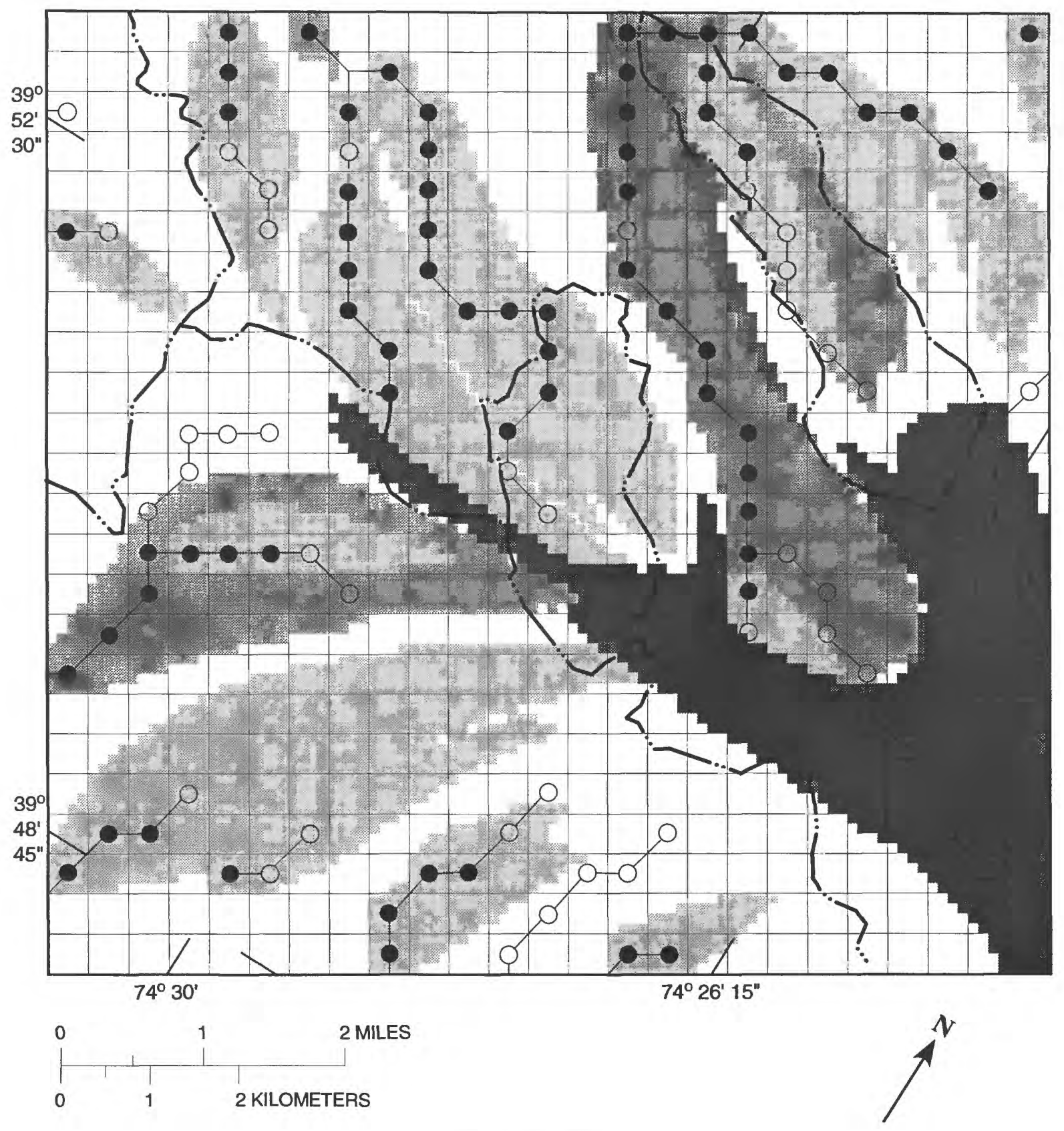

\section{EXPLANATION}

Source area of ground-water flow to first-order stream segments

Source area of ground-water flow to second-order stream segments

Source area of ground-water flow to third-order stream segments

Source area of seepage to the Piney Point aquifer

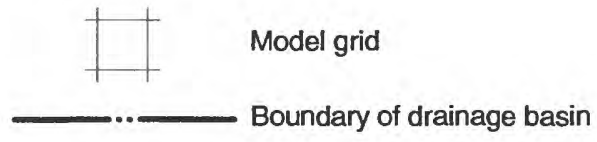

Stream segments -- Solid circles indicate drain cells that discharge ground water in simulation. Open circles indicate drain cells that receive negligible or no discharge in simulation. Connecting lines show relation between adjacent drain cells in stream network

Figure 15. Simulated source areas of ground-water flow to streams and seepage to the Piney Point aquifer in the subarea of the ground-water-flow model of the upper parts of the Rancocas Creek and Wading River Basins, New Jersey Pinelands, under unstressed conditions. 


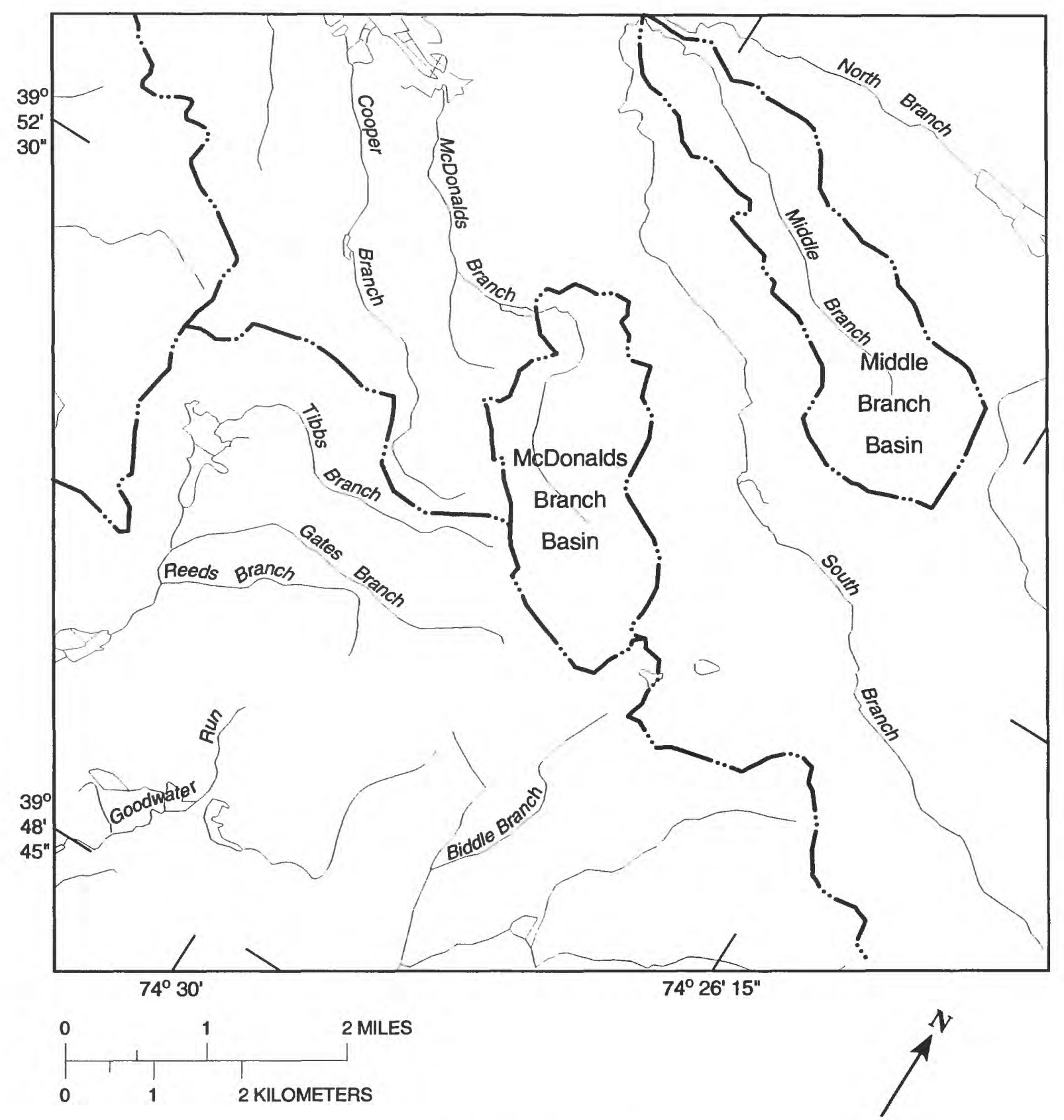

EXPLANATION

Boundary of drainage basin

Stream

Figure 16. Streams in the subarea of the upper parts of the Rancocas Creek and Wading River Basins, New Jersey Pinelands, near the regional drainage divide. 
The source area of flow to the Piney Point aquifer is adjacent to source areas of flow to first- and second-order streams; the flow field that results from ground-water movement between the water table and the Piney Point aquifer affects the configuration of the ground-water-flow fields in adjacent stream systems. At the upstream end of the South Branch source area, for example, the source area of flow to the Piney Point aquifer surrounds part of the source area of flow to the nearby stream system.

The configuration of the ground-water-flow field that results from flow between the water table and the Piney Point aquifer varies greatly vertically. The source area of flow to the Piney Point aquifer on the water table and the seepage area of that water at the base of the Kirkwood-Cohansey aquifer system in the McDonalds-Middle Branch subarea are shown in figure 17. The source and seepage areas were generated by using a 36-particle array on the top surface of the model cells. The source area of flow to the Piney Point aquifer is shown in figure 17a. (Figure 15 shows the same configuration of the source area of flow to the Piney Point aquifer in the larger modeled area.)

The points at which the flow paths of ground water traveling to the Piney Point aquifer intersect the base of the Kirkwood-Cohansey aquifer system are shown in figure 17b. The pattern indicates that flow diverges from the area on the water table into a broader area with an entirely different shape at the bottom of the Kirkwood-Cohansey aquifer system. The variation in the spacing of points indicates that the flow rates vary over the area. In general, flow rates are higher in zones in the seepage area in which the point density is high than in zones in which the point density is low.

The simulated ground-water budget for a rectangular block of the Kirkwood-Cohansey aquifer system underlying the 48.4- $\mathrm{mi}^{2}$ area for four scenarios -- one of unstressed conditions and three of stressed conditions (discussed in the following section) -- are shown in table 6. The budget component "lateral boundaries" refers to ground water entering or leaving this block of aquifer through the cell faces that define its border. In the "unstressed" scenario, almost 39 percent $(17.75 \mathrm{Mgal} / \mathrm{d})$ of the recharge leaves this small part of the aquifer. When withdrawals are absent, ground-water flow to streams constitutes about 44 percent $(20.03 \mathrm{Mgal} / \mathrm{d})$ of the discharge, whereas nearly 15 percent $(6.68 \mathrm{Mgal} / \mathrm{d})$ seeps downward to the Piney Point aquifer.

\section{SIMULATED EFFECTS OF ALTERNATIVE WITHDRAWAL STRATEGIES ON GROUND-WATER-FLOW PATTERNS}

Although much of the modeled area lies within the Pinelands Reserve and other areas where development is minimal, an understanding of the possible ground-water diversions that can occur as a result of stress on the ground-water system is essential for effective water-supply management. In this section, results of simulation of four scenarios of ground-water withdrawals near McDonalds Branch and from the Piney Point aquifer are described and analyzed by using a particle tracker to determine the effects of withdrawal stresses. The analysis is restricted to the previously described 48.4- $\mathrm{mi}^{2}$ subarea of the modeled system that includes the McDonalds Branch and Middle Branch Basins. The subarea was selected to represent a hypothetical area of concern to demonstrate the effects of withdrawals on flow in a previously unstressed system and the sensitivity of ground-water response to withdrawals at different sites.

\section{Induced Stress from a Withdrawal Well}

Withdrawals were simulated in a cell located on the divide in the top layer of the model (well 1 in fig. 18) and, in another simulation, in a cell between McDonalds Branch and South Branch west of the $\mathrm{McDonalds}$ Branch Basin (well 2 in fig. 19). A simulated flow rate of $1.85 \mathrm{Mgal} / \mathrm{d}$ was used in each scenario. The withdrawals were assumed to be in equilibrium with flow in the system so that no change in storage occurred over time. Apart from the addition of wells, no other changes were made to model input; 
A

\section{EXPLANATION}

Model grid

- Stream cell

Points of origin of flow paths on water table (A),

and points where flow

paths intersect base of Kirkwood-Cohansey aquifer system (B)

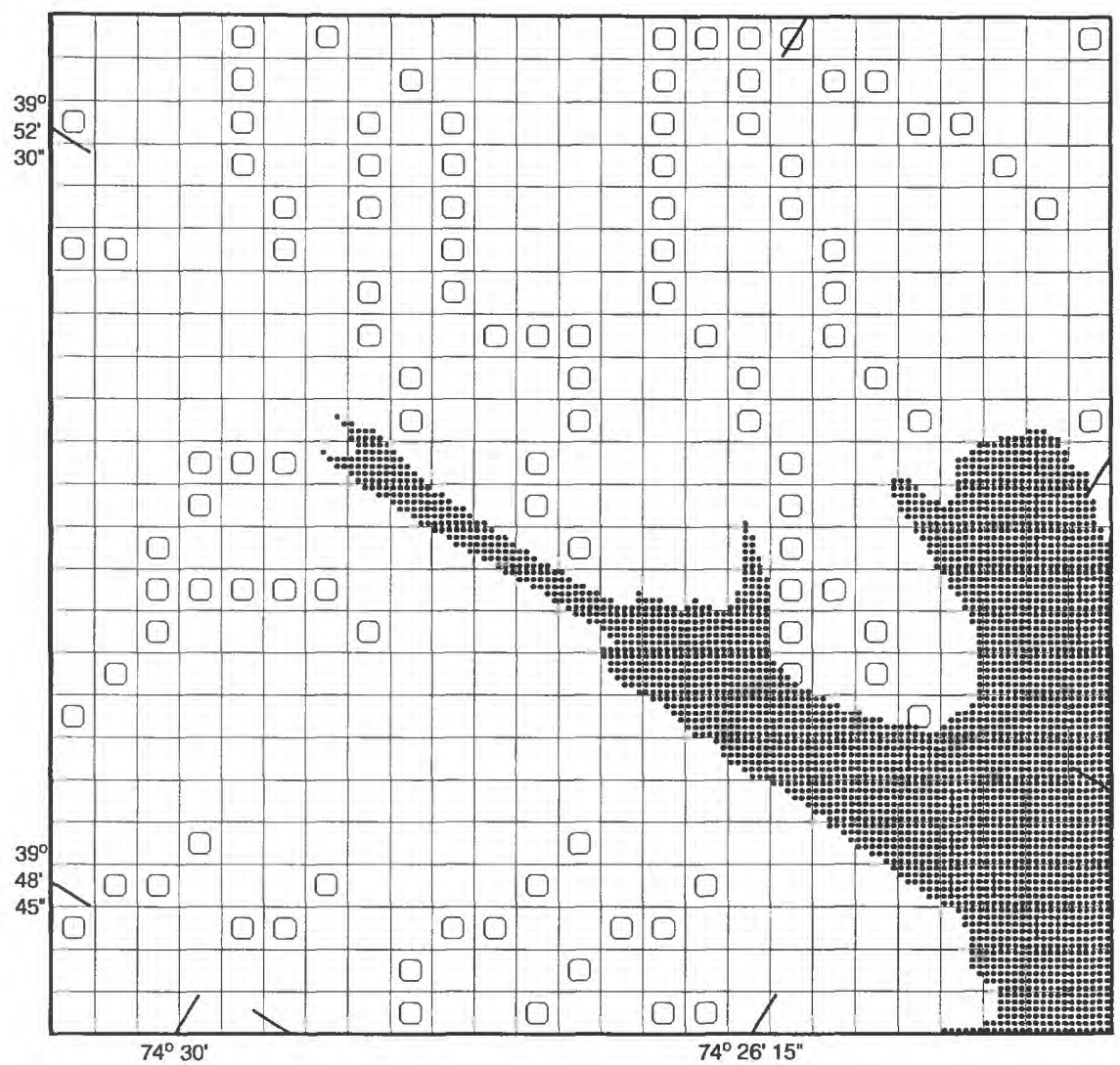

B
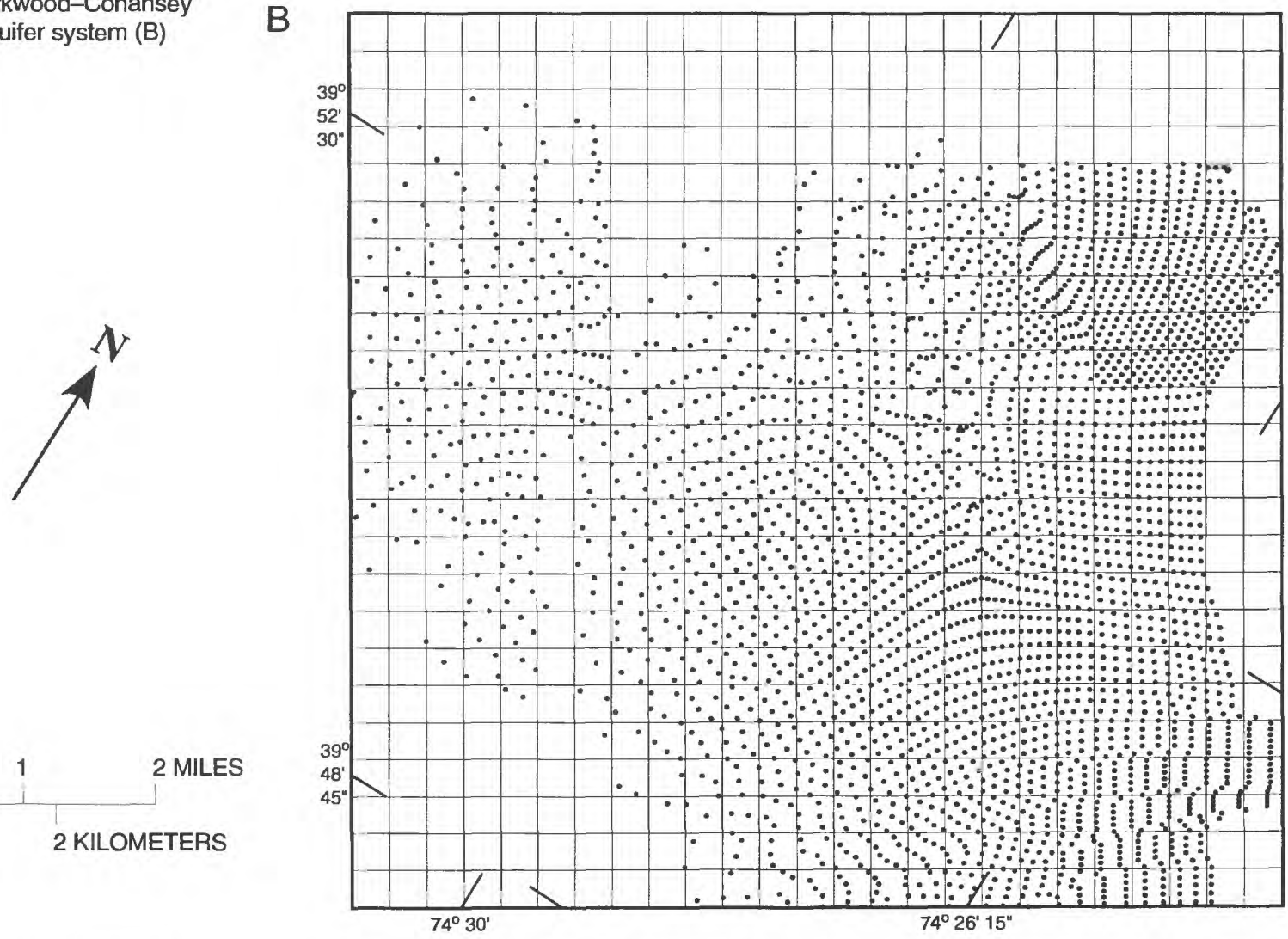

Figure 17. (A) Simulated source area of recharge to the Piney Point aquifer, and (B) simulated seepage area of flow to the Piney Point aquifer at the base of the Kirkwood-Cohansey aquifer system, in the subarea of the ground-water-flow model of the upper parts of the Rancocas Creek and Wading River Basins, New Jersey Pinelands, near the regional drainage divide. 
Table 6. Simulated ground-water budget for the subarea of the ground-water-flow model of the upper parts of the Rancocas Creek and Wading River Basins, New Jersey Pinelands, near the regional divide for four flow simulations

[Mgal/d, million gallons per day]

\begin{tabular}{|c|c|c|c|c|}
\hline \multirow[b]{2}{*}{$\begin{array}{l}\text { Ground-water-budged } \\
\text { component }\end{array}$} & \multicolumn{4}{|c|}{ Scenarios } \\
\hline & $\begin{array}{l}\text { Unstressed } \\
\text { (Mgal/d) }\end{array}$ & $\begin{array}{l}\text { Well } 1 \\
\text { (Mgal/d) }\end{array}$ & $\begin{array}{l}\text { Well } 2 \\
\text { (Mgal/d) }\end{array}$ & $\begin{array}{l}\text { Withdrawals from } \\
\text { Piney Point aquifer } \\
\text { (Mgal/d) }\end{array}$ \\
\hline \multicolumn{5}{|l|}{ In: } \\
\hline $\begin{array}{l}\text { Flow from surface-water } \\
\text { bodies }^{1}\end{array}$ & 0.25 & 0.25 & 0.33 & 0.29 \\
\hline Recharge & 43.77 & 43.77 & 43.77 & 43.77 \\
\hline $\begin{array}{l}\text { Leakage from underlying } \\
\text { aquifer }\end{array}$ & .21 & .21 & .25 & .00 \\
\hline $\begin{array}{l}\text { Inflow through lateral } \\
\text { boundaries }\end{array}$ & 1.41 & 1.49 & 1.41 & 1.64 \\
\hline \multicolumn{5}{|l|}{ Out: } \\
\hline $\begin{array}{l}\text { Flow to surface-water } \\
\text { bodies }^{1}\end{array}$ & 1.18 & 1.17 & 1.14 & .84 \\
\hline Flow to wells & .00 & 1.85 & 1.85 & .00 \\
\hline $\begin{array}{l}\text { Leakage to underlying } \\
\text { aquifer }\end{array}$ & 6.68 & 6.43 & 6.66 & 12.88 \\
\hline Flow to streams & 20.03 & 18.77 & 18.56 & 15.08 \\
\hline $\begin{array}{l}\text { Outflow through lateral } \\
\text { boundaries }\end{array}$ & 17.75 & 17.50 & 17.55 & 16.90 \\
\hline
\end{tabular}

\footnotetext{
${ }^{1}$ Other than streams
} 
however, although the initial evapotranspiration rates were retained for these simulations, evapotranspiration rates in the ground-water system most likely would decrease in response to the withdrawals. The decrease in water levels induced by the withdrawals would decrease the amount of ground water available to vegetation and to evaporation from the shallow ground-water zone.

The configuration of source areas of flow to streams and the Pincy Point aquifer resulting from the simulation of withdrawals from well 1 is shown in figure 18. The source area of flow to well 1 extends over the southeastern end of McDonalds Branch Basin and part of the drainage divide; it includes recharge areas that under unstressed conditions formed parts of the source areas of flow to the Piney Point aquifer and to Goodwater Run (fig. 16). Also, the source area of flow to Biddle Branch is reduced as a result of ground-water diversion to the well. Withdrawals from well 1 appear to have negligible effects on groundwater flow to other discharge outlets that are near the well.

The flow to well 1 (table 6) is derived mainly from flow to streams in the unstressed scenario. Base flow is reduced by $1.26 \mathrm{Mgal} / \mathrm{d}$. Flow out of the aquifer underlying the subarea through lateral boundaries and to the Piney Point aquifer also are reduced, but to a smaller extent.

The simulated effect of withdrawals from well 2 on the configuration of the source areas of flow to streams and the Piney Point aquifer is shown in figure 19. The source area of flow to well 2 is near the northwestern boundary of McDonalds Branch Basin. The source area is concentrated around the well but has a long, trailing end that is flanked by source areas of flow to South Branch, McDonalds Branch, and the Piney Point aquifer. The source area of flow to well 2 is discontinuous; small parts of the area are separated from the main area by a strip of the source area of flow to South Branch. The discontinuous parts of source areas of flow to the well indicate that the well discharge is composed of separate flows that originate at different locations on the surface and eventually converge to a common point of discharge.

The source areas of flow to streams adjacent to well 2 are most affected by the withdrawal. A discontinuity is created in part of the source area of flow to McDonalds Branch immediately to the west of well 2. The absence of a source area of flow along this stream segment does not indicate an absence of discharge but, rather, indicates that discharge to these cells is negligible. The quantity of discharge is too small to be estimated with the number of particles used in the particle-tracking simulation (one-sixteenth of the distributed recharge rate per cell). Ground-water discharge to the South Branch also has been reduced; the size of the source area of flow to the third-order stream segment has been reduced.

Discharge to streams is affected more strongly by withdrawals from well 2 than well 1 , but flow to the Piney Point aquifer is not significantly affected by withdrawals in either scenario (table 6). Because the withdrawal rates in both scenarios were identical and recharge rates were not changed, the source areas of flow to the wells also must be of equal area. Nevertheless, the effects of the withdrawals on the groundwater budget and on the distribution of recharge areas differ considerably. The source area of flow to well 2 spans a longer but narrower area of the water table than the source area of flow to well 1, which is concentrated around the well site. Consequently, the location as well as withdrawal rates can be an important factor to consider in assessing effects resulting from ground-water withdrawals. 




EXPLANATION

Source area of ground-water flow to first-order stream segments

Source area of ground-water flow to second-order stream segments

Source area of ground-water flow to third-order stream segments

Source area of seepage to the Piney Point aquifer

Source area of ground-water flow to withdrawal well 1

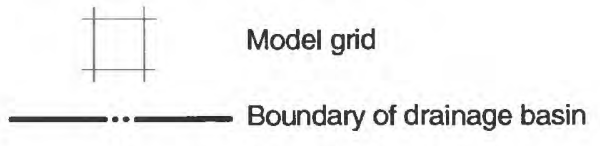

Stream segments -- Solid circles indicate drain cells that discharge ground water in simulation. Open circles indicate drain cells that receive negligible or no discharge in simulation. Connecting lines show relation between adjacent drain cells in stream network

(1) Withdrawal well 1

Figure 18. Simulated source areas of ground-water flow to streams, to the Piney Point aquifer, and to withdrawal well 1 located on the divide, in the subarea of the ground-water-flow model of the upper parts of the Rancocas Creek and Wading.River Basins, New Jersey Pinelands, with ground-water withdrawals from withdrawal well 1. 




EXPLANATION

Source area of ground-water flow to first-order stream segments

Source area of ground-water flow to second-order stream segments

Source area of ground-water flow to third-order stream segments

Source area of seepage to the Piney Point aquifer

Source area of ground-water flow to withdrawal well 1

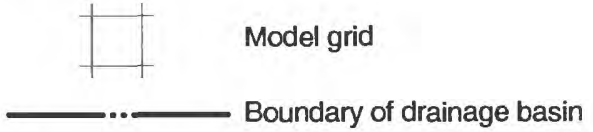

Stream segments - Solid circles indicate drain cells that discharge ground water in simulation. Open circles indicate drain cells that receive negligible or no discharge in simulation. Connecting lines show relation between adjacent drain cells in stream network

(O) Withdrawal well 1

Figure 19. Simulated source areas of ground-water flow to streams, to the Piney Point aquifer, and to withdrawal well 2 in the subarea of the ground-water-flow model of the upper parts of the Rancocas Creek and Wading River Basins, New Jersey Pinelands, with ground-water withdrawals from withdrawal well 2. 


\section{Induced Stress Caused by Withdrawals from the Piney Point Aquifer}

The scenario in which withdrawals from the Piney Point aquifer were simulated was intended to demonstrate the possible effects of withdrawals from the Piney Point aquifer (a confined aquifer) on ground-water-flow patterns in the overlying unconfined aquifer. Unlike in the previous simulations, where stress was applied locally in the area of interest, in this simulation the hydrologic effects of withdrawals from the Pincy Point aquifer could be discounted as being too remote from the area of interest to warrant concern.

The effect of withdrawals from the Piney Point aquifer was simulated by reducing heads in the aquifer between 10 and $15 \mathrm{ft}$ below those present under unstressed conditions. In this scenario it is assumed that ground-water withdrawals from the Piney Point aquifer are sufficient to maintain these reduced heads. Similar effects could result from withdrawals from several water-supply wells. This reduction in heads causes increased leakage from the overlying Kirkwood-Cohansey aquifer system by increasing the difference in head between the Piney Point aquifer and the Kirkwood-Cohansey aquifer system. Because the Piney Point aquifer was not modeled explicitly, the withdrawal rate cannot be specified nor is it intended to be comparable to that used in the previous simulations.

The source areas of flow within the subarea for this scenario are shown in figure 20. The source area of flow to the Piney Point aquifer occupies a considerably larger arca in this simulation than in the previous simulations. This expansion is offset by a reduction in the size of the source areas of flow to streams in the adjacent area. Source areas of flow to South, Middle, Cooper, Gates, and Biddle Branches as well as that to Goodwater Run all have been reduced. The ground-water budget for this scenario (table 6) shows that flow to the underlying aquifer has increased by $6.2 \mathrm{Mgal} / \mathrm{d}$ over the flow in the unstressed scenario, indicating that ground-water withdrawals from the Piney Point aquifer divert $6.2 \mathrm{Mgal} / \mathrm{d}$ from the overlying Kirkwood-Cohansey aquifer system. Leakage to the Piney Point aquifer accounts for 28 percent of the budget outflow from the subarea, compared to 14 percent for the unstressed case. Ground-water discharge to streams has been reduced, from about 44 percent of the budget outflow in the unstressed scenario to about 33 percent. However, these reductions are dispersed over many streams and indicate that ground-water-flow patterns in a particular location can be affected by changes in the flow to other areas of the system, irrespective of their proximity to the area of interest.

The simulated effects of withdrawals from the Piney Point aquifer on the Kirkwood-Cohansey aquifer system are sensitive to the vertical hydraulic conductivity of the basal part of the Kirkwood Formation (table 1). For example, if smaller conductivity values were used to represent the basal Kirkwood Formation in the flow simulation than those indicated in table 1, then seepage to the Piney Point aquifer would be reduced. If the purpose of this study were a more accurate quantitative determination of induced flow to the Piney Point aquifer, then (1) the Piney Point aquifer would need to be represented explicitly in the model and (2) additional data on the water-transmitting properties of the basal Kirkwood Formation would be needed.

\section{Effects of Withdrawals on Ground-Water Residence Time}

Ground-water diversions caused by withdrawals affect the residence time of ground water in the system. Figure 21 shows lines of equal residence time for the model subarea in the unstressed simulation (fig. 21a) and the alteration of those residence times under the conditions assigned to the simulation of withdrawals from well 1 (fig. $21 \mathrm{~b}$ ). Residence times in the area immediately adjacent to the well are greatly reduced (from greater than 80 years to less than 20 years) compared to those under unstressed conditions. Farther from the well, residence times have adjusted to the stress and lines of equal residence time 


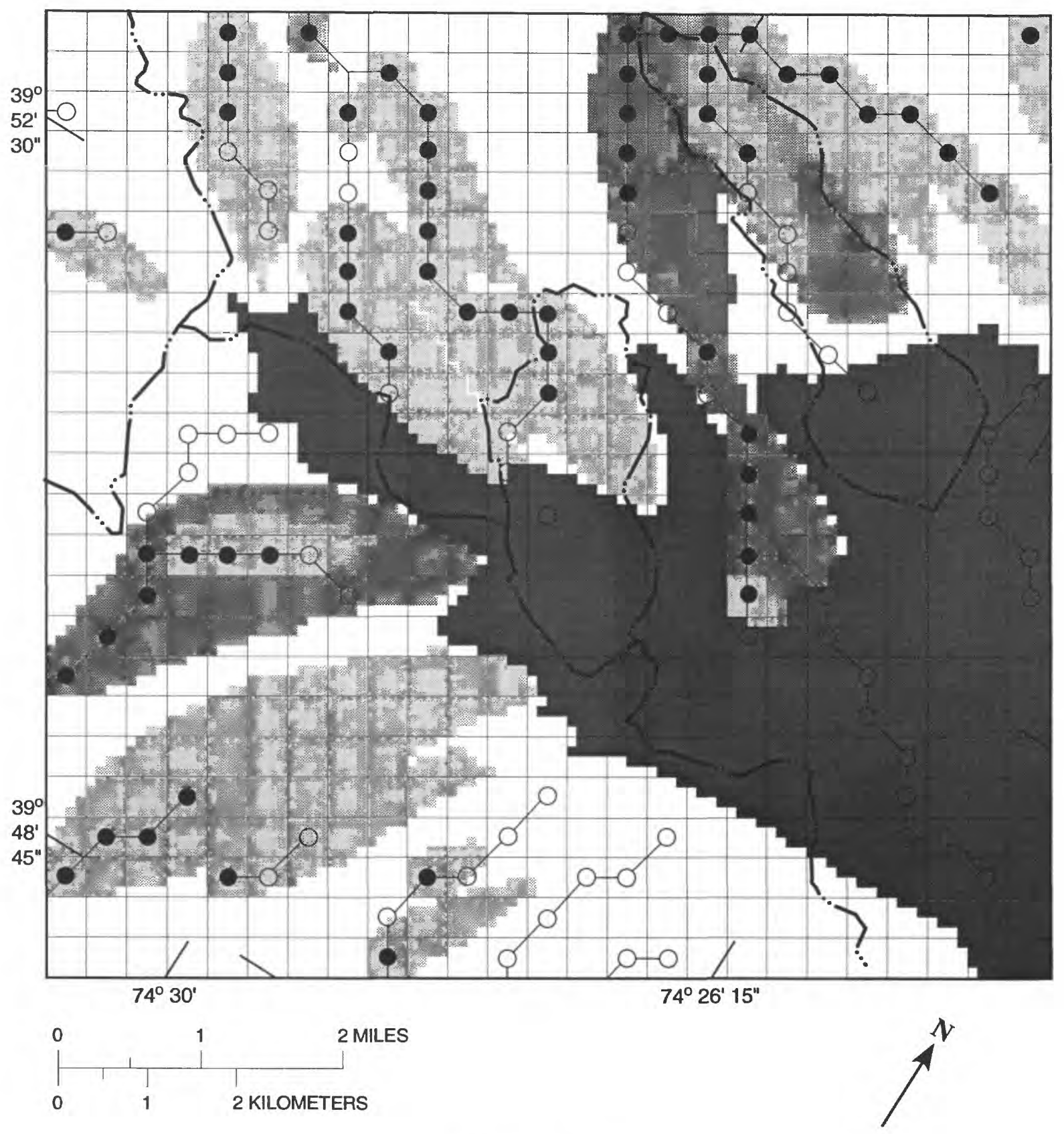

EXPLANATION

Source area of ground-water flow to first-order stream segments

Source area of ground-water flow to second-order stream segments

Source area of ground-water flow to third-order stream segments

Source area of seepage to the Piney Point aquifer
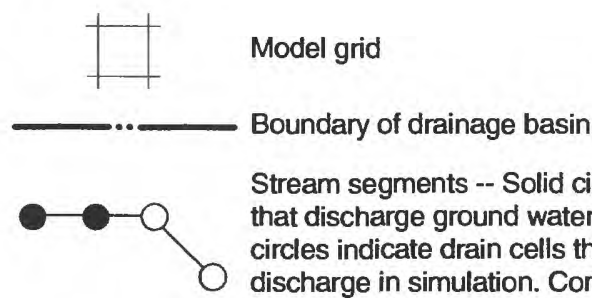

Stream segments -- Solid circles indicate drain cells that discharge ground water in simulation. Open circles indicate drain cells that receive negligible or no discharge in simulation. Connecting lines show relation between adjacent drain cells in stream network

Figure 20. Simulated source areas of ground-water flow to streams and to the Piney Point aquifer in the subarea of the ground-water-flow model of the upper parts of the Rancocas Creek and Wading River Basins, New Jersey Pinelands, with ground-water withdrawals from the Piney Point aquifer. 
are not significantly different but have different configurations than those simulated for unstressed conditions. These results indicate that unstressed ground-water residence times are altered significantly in the area surrounding the withdrawal well.

\section{SUMMARY AND CONCLUSIONS}

A steady-state model of ground-water flow in the upper parts of the Rancocas Creck and Wading River Basins in the New Jersey Pinelands was prepared. The model is based on previously reported hydrogeologic-framework information and includes the Kirkwood-Cohansey aquifer system, Piney Point aquifer, and Vincentown aquifer. The model simulates primarily the Kirkwood-Cohansey aquifer system and was calibrated against heads in observation wells and streamflow data from streamflow-gaging stations in the modeled area. The purpose of the study was to determine ground-water-flow patterns and estimate ground-water residence time in areas near major stream divides that are adjacent to McDonalds Branch Basin under unstressed and stressed hydrologic conditions. The design and calibration of the model were consistent with this purpose. The stressed conditions simulated include identical ground-water withdrawals from wells at two different locations, and unspecified withdrawals from the Piney Point aquifer that result in a reduction in heads in the aquifer of 10 to $15 \mathrm{ft}$. A particle-tracking postprocessor was used to determine flow paths in the ground-water-flow system and to demonstrate the alteration of the configuration of source areas of flow to streams and other discharge outlets that result from the groundwater withdrawals. Results of the flow simulation include the following:

(1) Under natural conditions, more than 98 percent of the ground water in the part of the Kirkwood-Cohansey aquifer system underlying the upper Rancocas Creek and Wading River Basins is derived from recharge. Less than 2 percent of the ground water comes from underlying aquifers. More than 87 percent of the ground water discharges to streams and wetlands. Ground-water seepage to the underlying Piney Point aquifer accounts for about 8 percent of discharge from the system. Areas near major drainage divides divert recharge to different parts of the basin or to adjacent basins; that is, divide areas are the source of flow to more remote parts of the system. Consequently, source areas of flow to small basins located near major drainage divides do not necessarily coincide with the physiographic boundaries of the basins. The source areas of flow to the Piney Point aquifer are limited to areas adjacent to the major stream divide. The drainage network serves as the most extensive and important discharge outlet for the aquifer system.

(2) Under natural conditions, ground water in most of the aquifer system remains there for less than 20 years and is then discharged to streams. The greatest ground-water residence times are greater than 200 years for recharge that enters the system near the divide. Ground-water residence times generally are greater in thicker parts of the aquifer, such as near the major divides, where vertical components of flow predominate, but smaller in thinner parts of the aquifer where horizontal flow components predominate. Residence times of ground water are affected significantly by withdrawals. Residence times greater than 80 years are reduced to less than 20 years in areas where a withdrawal rate of $1.85 \mathrm{Mgal} / \mathrm{d}$ is maintained.

(3) The configurations of source areas of flow to local stream systems and to the Piney Point aquifer are affected by the location of a withdrawal well. The source area of flow to the withdrawal well includes areas on the water table that would, under unstressed conditions, be incorporated into source areas of flow to streams or to the Piney Point aquifer. Simulated withdrawals of $1.85 \mathrm{Mgal} / \mathrm{d}$ at the divide have negligible effects on source areas of ground-water flow to adjacent streams, but capture recharge that under natural conditions would flow deep into the aquifer. Simulated withdrawals of $1.85 \mathrm{Mgal} / \mathrm{d}$ located $2 \mathrm{mi}$ from the divide, however, capture most recharge from source areas of flow to adjacent streams. Large-scale regional withdrawals that cause a 10- to 15 -foot decrease in heads in the Piney Point aquifer and divert 6.2 

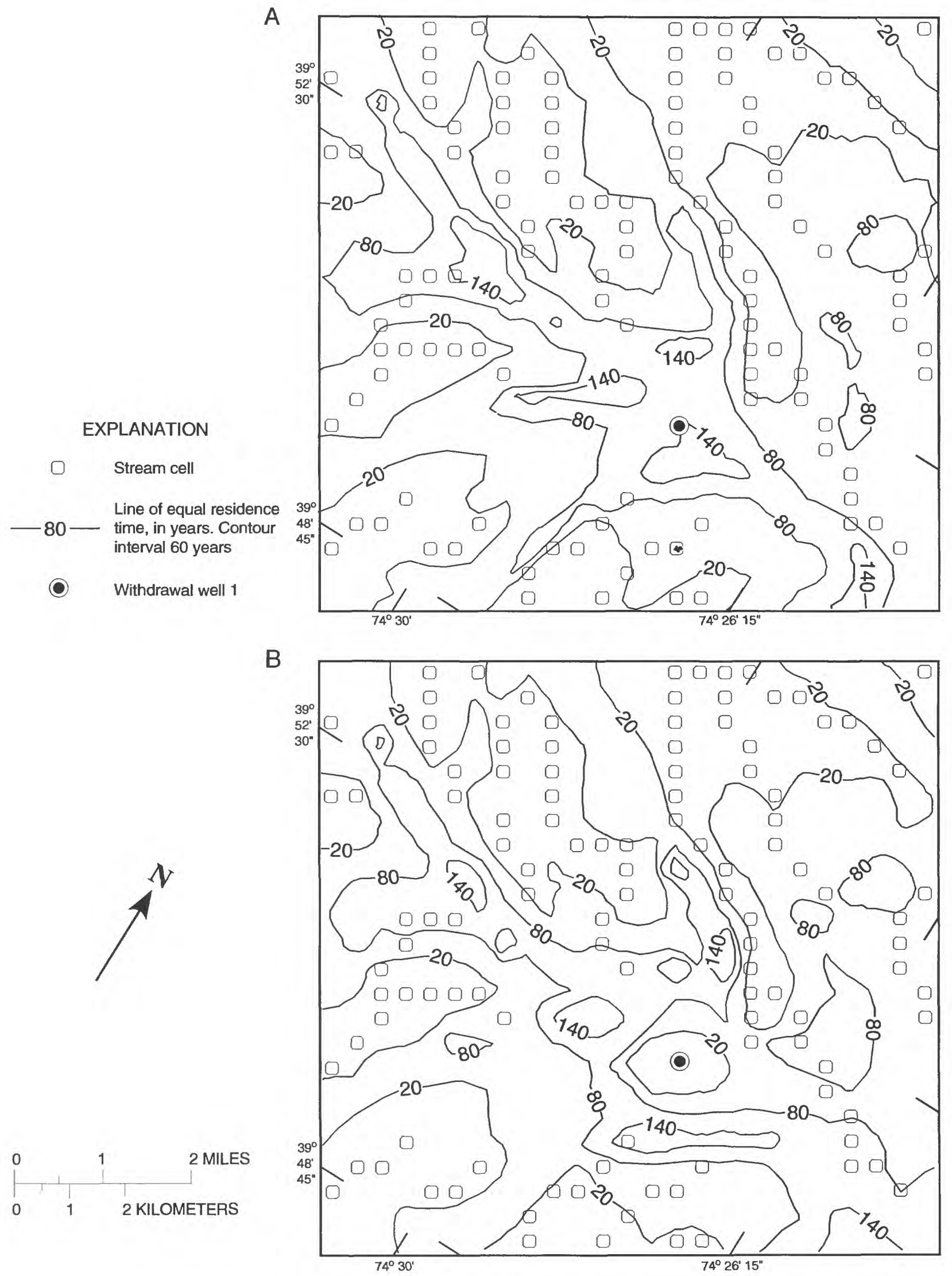

Figure 21. Simulated residence time under (A) unstressed conditions and (B) conditions of ground-water withdrawals from withdrawal well 1 in the subarea of the ground-water-flow model of the upper parts of the Rancocas Creek and Wading River Basins, New Jersey Pinelands. 
$\mathrm{Mgal} / \mathrm{d}$ of ground water from the Kirkwood-Cohansey aquifer system significantly increase the source areas of flow to the Piney Point aquifer by diverting ground water from local stream networks in upland basin arcas.

(4) Results of withdrawal simulations indicate that well-location schemes applied in the Kirkwood-Cohansey aquifer system can mitigate the adverse effects of withdrawals on streams and that large-scale regional withdrawals in confined aquifers can adversely effect streams although the effects are dispersed over numerous streams. 


\section{REFERENCES CITED}

Harbaugh, A. W., and Tillcy, C. L., 1984, Stcady-state computer model of the water-table aquifer in the Mullica River Basin, the Pine Barrens, New Jersey: U.S. Geological Survey Water-Resources Investigations Report 84-4295, 37 p.

Johnsson, P. A., and Barringer, J. L., 1993, Water quality and hydrogcochemical processes in McDonalds Branch Basin, New Jersey Pinelands, 1984-88: U.S. Geological Survey Water-Resources Investigations Report 91-4081, 111 p.

Lang, S. M., and Rhodehamel, E. C., 1963, Aquifer test at a site on the Mullica River in the Wharton Tract, southern New Jersey: International Association Scientific Hydrology Bulletin, v. 8, no. 2, p. 31-38.

Lord, D. G., Barringer, J. L., Johnsson, P. A., Schuster, P. F., Walker, R. L., Fairchild, J. E., Sroka, B. N., and Jacobsen, E., 1990, Hydrogeochemical data from an acidic deposition study at McDonalds Branch Basin in the New Jersey Pinclands, 1983-86: U.S. Geological Survey Open-File Report $88-500,132 \mathrm{p}$.

Mackey, M. L., 1971, Soil survey of Burlington County, New Jersey: U.S. Department of Agriculture Soil Conservation Service, Soil Survey Service, 120 p.

Martin, Mary, in press, Ground-water flow in the New Jersey Coastal Plain: U.S. Geological Survey Professional Paper 1404-H, 249 p.

McDonald, M.G., and Harbaugh, A.W., 1988, A modular three-dimensional finite- difference groundwater flow model: U.S. Geological Survey Techniques of Water-Resources Investigations, book 6, chap. A 1, 586 p.

Minard, J. P., and Owens, J. P., 1963, Pre-Quaternary geology of the Browns Mills Quadrangle, Burlington Co., New Jersey: U.S. Geological Survey Map GQ-264, scale 1:24,000, 1 sheet.

1964, Pre-Quaternary geology of the Pemberton Quadrangle, Burlington Co., New Jersey:

U.S. Geological Survey Map GQ-262, scale 1:24,000, 1 sheet.

1975, Geologic map of the surficial deposits in the Trenton area, New Jersey and Pennsylvania:

U.S. Geological Survey Miscellancous Investigations Series Map I-884, scale 1:48,000, 1 sheet.

Pollock, D. W., 1989, Documentation of computer programs to compute and display pathlines using results from the U.S. Geological Survey modular three-dimensional finite-difference ground-water flow model: U.S. Geological Survey Open-File Report 89-381, 188 p.

Rhodehamel, E. C., 1970, A hydrologic analysis of the New Jersey Pine Barrens Region: New Jersey Department of Environmental Protection, Division of Water Policy and Supply, Water Resources Circular No. 22, 35 p.

1973, Geology and water resources of the Wharton Tract and Mullica River Basin in southern New Jersey: New Jersey Department of Environmental Protection, Division of Water Resources, Special Report No. 36, 57 p. 


\section{REFERENCES CITED--Continued}

Sloto, R. A., 1991, A computer method for estimating ground-water contribution to streamflow using hydrograph-separation techniques, in Balthrop, B. H., and Terry, J. E., eds., U. S. Geological Survey National Computer Technology Meeting Proceedings, Phoenix, Arizona, Nov. 14-18, 1988: U.S. Geological Survey Water-Resources Investigations Report 90-4162, p. 101-110.

Strahler, A. N., 1952, Dynamic basis of geomorphology: Geological Society of America Bulletin, v. 63, p. 923-38.

Zampella, R. A., and Moore, G., 1992, Gradient analysis of pitch pine (Pinus rigida Mill.) lowland communities in the New Jersey Pinelands: Bulletin of the Torrey Botanical Club, v. 119, no. 3, p. 253-261.

Zapecza, O. S., Voronin, L. M., and Martin, M., 1987, Ground-water-withdrawal and water-level data used to simulate regional flow in the major Coastal Plain aquifers of New Jersey: U.S. Geological Survey Water-Resources Investigations Report 87-4038, 120 p., 10 pls.

Zapecza, O. S., 1989, Hydrogeologic framework of the New Jersey Coastal Plain: U.S.Geological Survey Professional Paper 1404-B, 49 p., 24 pls. 